This document is the accepted manuscript version of the following article:

Fumey, B., Weber, R., \& Baldini, L. (2019). Sorption based long-term thermal energy storage process classification and analysis of performance limitations: a review. Renewable and Sustainable Energy Reviews, 111, 57-74. https://doi.org/10.1016/j.rser.2019.05.006

This manuscript version is made available under the CC-BY-NC-ND 4.0

1icense http://creativecommons.org/1icenses/by-nc-nd/4.0/

\title{
Sorption based long-term thermal energy storage - Process classification and analysis of performance limitations: A Review
}

Fumey B. ${ }^{1 *}$, Weber R. ${ }^{1}$, Baldini L. ${ }^{1}$

1 = Empa, Swiss Federal Laboratories for Materials Science and Technology, Ueberlandstrasse 129, 8600 Duebendorf, Switzerland

* = Corresponding author details, benjamin.fumey@empa.ch

Declaration of interest: None.

Abstract

In sorption heat storage, one of the sources of discrepancy between theoretical material based energy storage potential and resulting system performance is the choice of process type. In this paper, in order to understand this performance deviation, a sorption heat storage process categorisation is proposed. This is followed by a review of reported sorption systems categorised according to the proposed process classification. An analysis of the reported systems is then undertaken focusing on the ratio of resulting temperature gain in sorption (ad- or absorption) compared to required temperature lift in desorption. This measure is termed temperature effectiveness and enables a form of system performance evaluation in the broad landscape of sorption thermal energy storage demonstrators. It is argued that other performance parameters such as volumetric energy storage density and volumetric charge and discharge power density are not adequate for comparison due to the highly varying testing conditions applied. From the system evaluation, it is seen that best temperature effectiveness is generally found in a closed, transported process with the ability of single sorbent pass and true counter flow heat exchange.

Highlights

- There are four basic sorption thermal energy storage processes, open fixed, open transported, closed fixed and closed transported.

- Temperature effectiveness, the ratio of resulting sorption temperature lift to required desorption temperature lift, is a universal means for sorption heat storage system performance comparison.

- Closed transported sorption thermal energy storage systems show the best performance in respect to temperature effectiveness.

Keywords

- Long-term sorption thermal energy storage

- Temperature effectiveness

- Process categorisation

- System performance evaluation

- Comparison across basic designs

- Evaluation of design dependent performance degradation

Word Count

7307 words, excluding title, author names and affiliations, keywords, abbreviations, table/figure captions, acknowledgments and references. 
List of abbreviations

GTLs: Gross temperature lift resulting in sorption (adsorption or absorption)

GTL $_{D}$ : Gross temperature lift required in desorption

HTF: Heat transport fluid

HMX: Heat and mass exchanger

TE: Temperature effectiveness, GTLs/GTL

WBT: Wet bulb temperature

\section{Introduction}

Thermal energy storage is an important enabler for the utilisation of renewable energy as well as waste energy. It is applied on a time scale from hours and days up to several months, in the latter case referred to as long-term or seasonal thermal energy storage [1, 2]. This is an important asset for renewable heating of buildings [3-7]. Research activities in the field of long-term thermal energy storage have increased and a broad range of system designs employing different storage materials has been evaluated and tested. Principal criteria for long-term thermal energy storage are among others, high energy density, low thermal loss during storage time and low investment cost. The last mentioned is a critical factor, due to the low number of cycles and thus low overall energy turnover leading to high energy capacity cost (EUR/kWh) [8]. The discipline of long-term thermal energy storage is divided into sensible, latent, and sorption thermal energy storage involving adsorption, liquid absorption and solid absorption with hydration and hydroxide reaction. In this study all processes will be referred to as sorption. Both sensible and latent storage systems suffer continuous heat loss, a substantial challenge for long-term storage applications, countered by large scale sensible storage systems [9] and supercooling in latent systems [10,11].

Sorption thermal energy storage follows the concept of reversible decomposition reaction process [12-19]. In the action of sorption, sorbate in its gaseous phase is adhered to or penetrates into a solid or liquid sorbent $[13,14,20]$. A combination of thermophysical and thermochemical processes are involved [21, 22]. This approach has the prospect for high energy density and lossless storage over time making it attractive for long-term heat storage [14, 23, 24]. Not actually heat but the potential to regain heat at a later point in time and at elevated temperature is stored, functioning as a chemically driven heat pump accessing heat from a low temperature source. Temperature swing is usually followed in the process [13] involving a temperature difference defined and referred to as gross temperature lift (GTL). In desorption, heat is employed, effecting a $G T L_{D}$ in order to remove sorbate, typically water from the sorbent through evaporation, reaching an increase in sorbent mass fraction and establishing a potential for sorption. In the sorption process on the other hand, sorbate is evaporated and adheres to or penetrates into the sorbent whereby the sorbent mass fraction declines and sorbate heat of condensation as well as heat of reaction is released reaching a material and mass fraction specific $\mathrm{GTL}_{\mathrm{s}}$.

Some criteria for choice of sorption materials stated in literature are [20, 23, 25, 26]:

- Desorption and sorption temperatures fitting to specific application

- High affinity of sorbent to sorbate - (affecting both GTL as well as volumetric charge and discharge power)

- High specific volumetric uptake of sorbate on sorbent - (affecting volumetric energy storage density)

- Substantially higher volatility of sorbate than sorbent - (for good separation through evaporation) 
- Good mass and heat transfer characteristics - (affecting charge and discharge power)

- Good chemical and mechanical stability - (affecting cycle stability)

- Favourable life cycle properties such as ecology and embodied emissions - (positively affecting sustainability)

- Low material price - (affecting economic viability)

Other criteria considered are corrosiveness, toxicity and moderate operation pressure.

Nevertheless, these issues are disputable and appropriate coating and system engineering solutions may be found to mitigate potential negative impact performance, longevity or acceptance.

In the present work, contrary to many other review papers on long-term sorption thermal energy storage systems, a critical reflection on performance and comparison of various systems published in literature is made. There are four basic measures of performance that can be applied. These are: GTL, volumetric energy storage density, volumetric charge and discharge power density, and charge to discharge round trip efficiency [20, 23, 25, 26]. Previous review papers [18, 27-31] have followed the practice of citing power and energy density of various technologies and proof of concept systems as reported. This can be misleading, due to the substantial dependency of both volumetric energy storage density and volumetric charge and discharge power density on operating temperatures. Even if operating temperatures are specified, due to the non-uniform testing parameters direct comparison cannot be made. Energy density and power density comparison between different systems is only possible if system tests are performed at defined application specific operating temperatures and if clear definition of referred volume in respect to material or system is reported [32]. For this reason, in this paper a system evaluation based on the reported ratio of resulting $G T L_{s}$ in sorption in respect to the required $G T L_{D}$ in desorption defined as temperature effectiveness (TE) is resorted to. GTL is a measure that can be applied along the scale from material to component and system, as a means of analysis of performance reduction along the scales, and is applicable for all sorption materials [32]. In this work the ratio of GTLs to $G T L_{D}$ referred to as TE is employed as a method to describe how well the system takes advantage of the full potential of the employed storage material. This enables a comparison between the systems as well as the basic processes used. Even though operation dependencies remain in this evaluation, this approach is substantially more robust since dependency is reduced to the sorbate vapour pressure. In as far as the vapour pressure remains constant both in desorption and sorption, theoretical temperature effectiveness is unity. Figure 1 shows different isosteres for aqueous $\mathrm{NaOH}$ (left) and zeolite (right) illustrating vapour pressure dependency of the GTL. In the diagrams the theoretical GTL at $1 \mathrm{kPa}$ is compared to the GTL at $10 \mathrm{kPa}$ vapour pressure. It is clearly shown that at greater sorbent vapour pressure the GTL increases. This is noted by the red circled line.

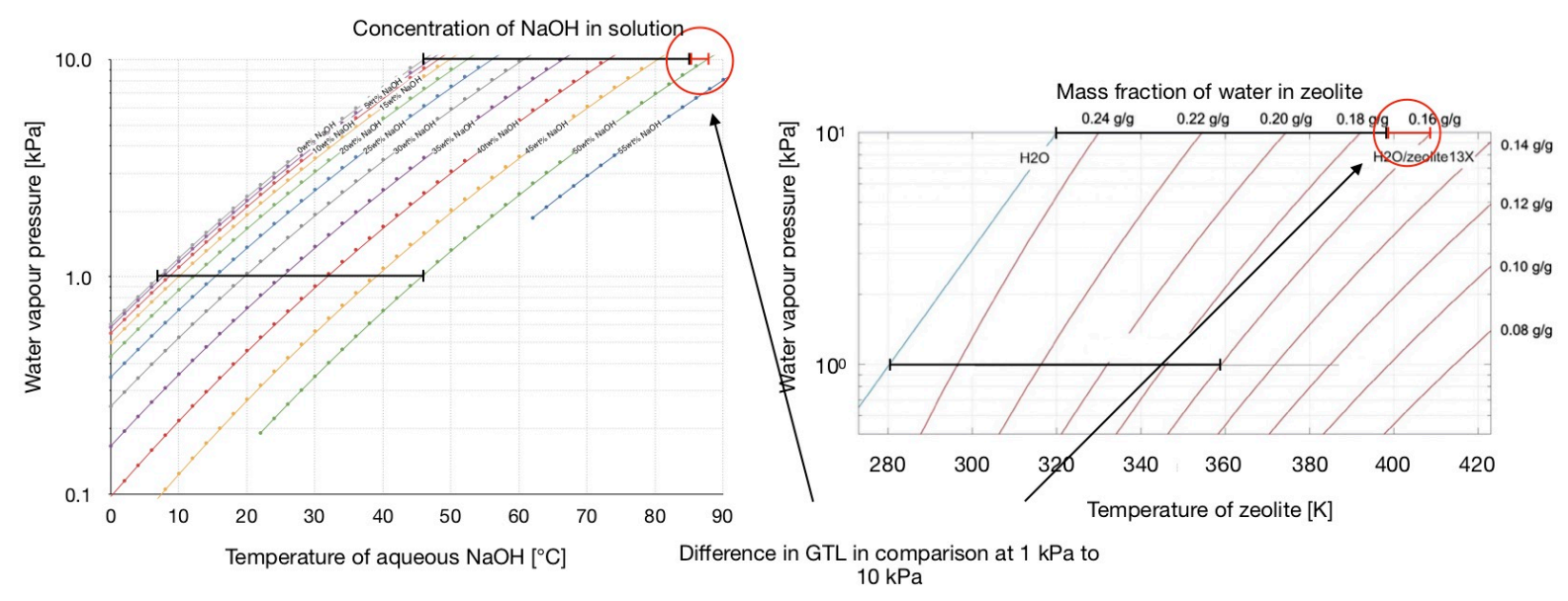


Figure 1: Isosteres of aqueous $\mathrm{NaOH}$ [33] on the left side and zeolie [34] on the right side, at varying sorbate mass fractions. Indicated is the difference between GTL evaluated at a vapour pressure of $1 \mathrm{kPa}$ and $10 \mathrm{kPa}$ respectively.

In the application as long-term thermal storage, it is expected that the vapour pressure in desorption is typically greater than the respective pressure in sorption. Thus results that $G T L_{s}$ is smaller than GTL $L_{D}$ and TE is less than unity. In the case where non-realistic vapour pressure conditions are followed, in a sense that higher pressure is taken in sorption than in desorption this leads to a more favourable TE evaluation.

TE as a measure of comparison between sorption systems thus benefits from non-confinement to a specific material, system approach or testing procedure. Since GTL is a temperature difference, specific operating temperatures apart from the discussed vapour pressure are eliminated from the comparison and no reference to volume is required. These are both important criteria since no specific uniform testing procedure is followed in the reported experiments. In the comparison, high TE shows good temperature management performance, pointing to a reduced process based temperature drop both in sorption as well as desorption. For the analysis presented herein care is taken to resort to heat transport fluid (HTF) temperatures and not storage material temperatures as well as average temperatures where relevant in dynamic discharging processes. In addition, comments are made on unrealistic testing conditions in light of the application as domestic heat storage. Pictures of the systems used for comparison are provided to give the reader an understanding of how far these prototypes are from real application.

\section{Sorption thermal energy storage system processes}

Systems focussed on in research and reported in literature can be classified into the process variations open versus closed [23] and fixed versus transported [13]. The former refers to material contact to the ambient air and the latter deals with sorbent material handling. A similar process classification is found proposed by [35] whereby reference is made to open, closed and liquid.

According to [36], some long-term thermal energy storage system challenges are:

- Choice of the best process (open or closed)

- Heat and mass exchanger (HMX) design and the reactor configuration

- Pressure drop

- Efficiency

- Cost

To date, choice of process, $\mathrm{HMX}$ design as well as therefrom resulting system design is largely based on choice of sorbent material. Sorbents that react with $\mathrm{CO}_{2}$, are hazardous or easily airborne, are studied in closed systems [37], and non-hazardous mainly solid materials are often employed in open systems for reason of their simplicity [38]. Solid sorbents are primarily studied in fixed systems with some work done on agitated transported processes [39] and transported sorbent systems are largely used for liquids [37, 40]. Figure 2 illustrates the four basic sorption heat storage processes, separating open and closed on the x-access and fixed and transported on the $y$-access. Illustrations are numbered for further reference. 


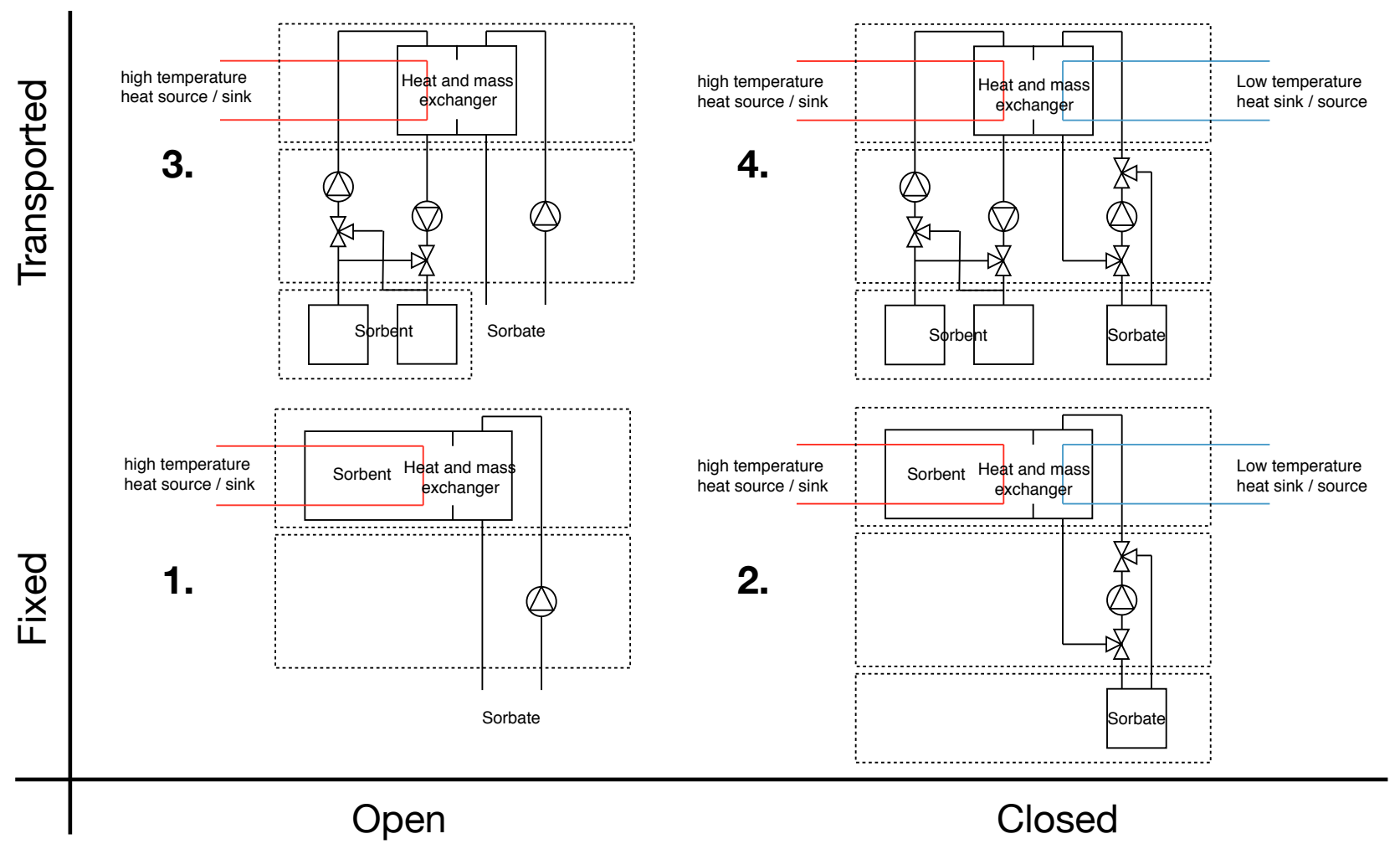

Figure 2: Illustration of basic sorption thermal energy storage processes.

\subsection{Open process}

The open process (illustration 1 and 3 in figure 2) operates solely with water as sorbate at atmospheric pressure. Sorbate is released to and sourced from the atmosphere [41]. This is illustrated by the pump symbol sourcing sorbate from the ambient. Systems based on the open process consist of a sorption and desorption HMX and a sorbent storage unit [13]. These systems do not have an evaporator and condenser unit or sorbate storage [42] and do not require vacuum or pressure compliance [41]. Thus, respective system complexity and volume are reduced. Discharge power directly depends on the given partial vapour pressure of sorbate in the ambient air [43]. This is generally low due to the low ambient temperature during the heating season. For this reason high volumetric air flow is required to reach adequate humidity supply [44]. This corresponds to a large thermal mass of inert carrier gas flow, limiting effective GTLs, discharge power and discharge efficiency through effected cooling [13]. In order to improve performance, air to air heat exchangers for heat recovery [39] and air humidifiers are employed [44], leading to an increase in complexity, system volume and cost. To increase vapour mass transport in the supply air, water is sprayed into the air stream bringing about an air temperature reduction at increased relative humidity. A general challenge in the open process is fouling on the sorbent material by heavy contaminations, bringing about a decline in temperature gain and power losses over time [20].

\subsection{Closed process}

In the closed process (illustration 2 and 4 in figure 2) the sorbate and sorbent is not in direct contact with the atmosphere and the sorbate is stored separately [13]. Thus, the open process exchanges matter while the closed process exchanges only heat with its surroundings. Closed systems consist of a sorption and desorption part as well as an evaporator and condenser part of the HMX, and sorbent and sorbate storage vessels [45]. They operate under sorbate atmosphere generally below atmospheric pressure, require good sealing [13] and are highly sensitive to the presence of non-condensing gases $[40,46]$. Closed systems reject heat to and source it from the 
ambient, typically the ground or the air [13] and are not bound to water as sorbate. Even so, water is often used due to its high phase change enthalpy from liquid to gas as well as generally high solubility in, and high affinity to, the respective sorbents [16]. Sorbent and sorbate are stored in separated vessels and the sensible part of the thermal energy employed for material separation is released to the atmosphere [13]. In sorption, the system output temperature is dependent on the low temperature heat source supplied to the evaporator and the sorbent material based GTL. In liquid sorbents GTL is dependent on sorbent mass fraction, whereby in solids it is dependent on the level of hydration.

In order to simplify comparison of closed and open systems in respect to vapour pressure and temperature gain, it is favourable to convert a given partial water vapour pressure in air to its wet bulb temperature (WBT). This corresponds to the respective evaporation temperature in a closed system. Since the WBT is always lower or equal to the ambient temperature, sink and source temperature is greater for closed systems than open systems. Thus, closed systems potentially require higher desorption temperatures but also release higher output temperatures than open systems [47]. This is most critical in the heat release in sorption, where it is important to reach high output temperature and maximum state of discharge. In this respect, closed systems are superior for the task of heating in buildings.

\subsection{Fixed process}

In the fixed bed process (illustration 1 and 2 in figure 2) the sorbent is kept stationary and often combined with the heat and mass exchanger [48]. No separate storage vessels are required [29], but an interdependence of desorption and sorption power and storage capacity results [13]. This is the most frequently followed process approach with solid sorbents [29, 43]. In the design of a fixed bed system it is important to know how sorption and desorption transitions progress through the bed $[20,49]$. This introduces the factors time and space into the analysis, leading to a dynamic character. Practical aspects such as mass transport, thermal conduction, dispersion phenomena at bed scale and volume change are important parameters to be considered [20]. Fixed bed systems generally suffer high pressure drop through the bed, reducing potential GTLs and requiring high parasitic power consumption [50]. In the desorption process, the complete sorbent bed is heated and has to be maintained at a material specific desorption temperature in order to reach the desired charged state [51]. In sorption the same process is followed, whereby through sorption based heat release, the complete bed is heated to the sorption temperature $[49,52]$. It follows that high thermal capacity of the material leads to system capacity loss. The sorption process is maintained until the output temperature drops below the minimum required output temperature, referred to as thermal breakthrough. The achievable storage density decreases drastically, when the thermal breakthrough temperature is increased [47]. In non-continuous sorption, sorbate mass transfer during inactive periods may occur and lead to the establishment of a new homogeneous state of charge at a lower potential $G T L_{s}$ and thus lower maximum output temperature in continued discharge [41]. Segmentation of storage vessels is employed in order to reduce issues with partial discharge [41], as well as enable discharge below breakthrough threshold through connection of segments in series [53]. Complexity in fixed bed application is increased when used for heat storage purposes through heat recovery, compared to other fixed bed striping processes. In the design of heat exchangers two approaches are followed, integrated including direct air heating [42, 44, 54] and separated [13]. Integrated heat exchangers are placed inside the fixed bed, while separated heat exchangers are positioned separate from the sorbent downstream from the sorbent supply. In both approaches, a mean temperature results. This temperature is substantially lower than the maximum temperature that can be reached based on the mass fraction specific GTLs.

\subsection{Transported process}

In the transported process (illustration 3 and 4 in figure 2) the heat and mass exchanger unit is separated from the sorbent storage [18]. Thus, separate storage vessels and means of sorbent transportation are required $[29,45]$. In this approach, heating power and thermal energy capacity are separated and can be individually designed and scaled for a specific application [13]. Due to 
the sorbent transport and continuous supply of fresh sorbent a steady state operation can be reached in the HMX [20], leading to continuous desorption or sorption with steady temperature and power profiles. This is in strong contrast to the fixed approach with dynamic profiles in the sorbent bed. Reaction processes are thus reduced to a fraction of the total storage material [55]. Sorbent transport parameters, such as viscosity and wetting behaviour for liquids [56] and grain size, material stability and flowability for solids [49] are important. Liquids are beneficial due to their simple transport by pumping $[18,45]$. For solids three basic reactor types are discussed, fluidised bed, extruder reactor and bulk flow reactor $[49,51]$. In the design of the heat and mass exchanger two characteristics are of significant benefit: sorbent single pass and counter flow. Recirculation of partly discharged sorbent, as typically employed in liquid sorbent chillers for good wetting, will lead to substantial reduction of the maximum discharge temperature due to mixing of fresh and partly discharged sorbent. Counterflow of sorbent and HTF is important for optimal heat exchange from sorbent to HTF. In this way maximum output temperature is reached due to continuous contact of HTF to fully charged sorbent and maximum discharge is enabled through cooling of sorbent to minimum heat transfer fluid temperature.

Considerations of best HMX design in terms of sorbent velocity, vessel height, contact area of sorbent to sorbate and heat transfer fluid, exposure time and sorbent flow distribution is important for optimum sorption kinetics both for liquid and solid sorbents. Due to the single pass requirement, slow flow with good liquid wetting or solid contact for improved thermal conductivity and high sorption surface area is key [45]. Residence time and hence, the HMX holdup is an important design feature in order to enable close fit to temperature and vapour pressure equilibrium for maximum storage capacity. It follows, that for heat storage, a heat and mass exchanger is designed on the basis of sufficient sorbent holdup or exposure time rather than on the basis of high mass transfer rate for maximum power density.

In comparing fixed systems to transported systems it can be concluded that, in as far as single pass and counter flow is followed, transported systems are superior both in low GTLD and high respective GTLs as well as in capacity [49]. Fixed systems are discharged to the HTF output temperature and maximum GTL is not reached due to bulk thermal capacity and internal mixing of heat from sorbent at varying mass fraction. Transported systems on the other hand are discharged to the heat transport input temperature, which is naturally lower than the output temperature [41]. Thus, fixed systems are sensitive in capacity to the output temperature [47] while transported systems are not [57] in as far as they reach the required temperature. For both fixed and transported systems capacity decreases if the HTF input temperature increases in respect to the sorbate evaporation temperature. Table 1 gives an overview of the process advantages and disadvantages.

Table 1: Advantages and disadvantages of the basic sorption thermal energy storage process types. 


\begin{tabular}{|c|c|c|c|}
\hline Process & Comment & Advantages & Disadvantages \\
\hline Open fixed & $\begin{array}{l}\text { - limited to water as } \\
\text { sorbate } \\
\text { - may require air to air } \\
\text { heat exchanger and air } \\
\text { humidifier } \\
\text { - power and capacity are } \\
\text { interlinked }\end{array}$ & $\begin{array}{l}\text { - operation at } \\
\text { atmospheric pressure } \\
\text { - only } 1 \mathrm{HMX} \text { needed } \\
\text { - no sorbate storage } \\
\text { needed } \\
\text { - no sorbent transport } \\
\text { required } \\
\text { - possibility to use } \\
\text { process air for heat } \\
\text { exchange }\end{array}$ & $\begin{array}{l}\text { - low vapour pressure in } \\
\text { ambient air } \\
\text { - requires high } \\
\text { volumetric air flow } \\
\text { - issues with fouling of } \\
\text { sorbent } \\
\text { - only for non-hazardous } \\
\text { sorbents } \\
\text { - dynamic process } \\
\text { parameters } \\
\text { temperature and power } \\
\text { - batch wise desorption } \\
\text { and sorption and } \\
\text { capacity loss under } \\
\text { discontinuous operation } \\
\text { - high parasitic heat } \\
\text { capacity } \\
\text { - high pressure drop for } \\
\text { air based heat } \\
\text { exchange } \\
\text { - reduced GTLs } \\
\text { - maximum discharge to } \\
\text { output temperature }\end{array}$ \\
\hline $\begin{array}{l}\text { Open } \\
\text { transported }\end{array}$ & $\begin{array}{l}\text { - limited to water as } \\
\text { sorbate } \\
\text { - may requires air to air } \\
\text { heat exchanger and air } \\
\text { humidifier } \\
\text { - separate scaling of } \\
\text { power and capacity }\end{array}$ & $\begin{array}{l}\text { - operation at } \\
\text { atmospheric pressure } \\
\text { - only } 1 \mathrm{HMX} \text { needed } \\
\text { - no sorbate storage } \\
\text { needed } \\
\text { - steady state process } \\
\text { - continuous desorption } \\
\text { and sorption } \\
\text { - capable of single pass } \\
\text { and counter flow } \\
\text { - maximum GTLs } \\
\text { - discharge to minimum } \\
\text { input temperature } \\
\text { - possibility to use } \\
\text { process air for heat } \\
\text { exchange }\end{array}$ & $\begin{array}{l}\text { - low vapour pressure in } \\
\text { ambient air } \\
\text { - } \text { requires high } \\
\text { volumetric air flow } \\
\text { - issues with fouling of } \\
\text { sorbent } \\
\text { - only for non-hazardous } \\
\text { sorbents } \\
\text { - Increase in complexity, } \\
\text { storage vessels and } \\
\text { means of transport }\end{array}$ \\
\hline
\end{tabular}




\begin{tabular}{|c|c|c|c|}
\hline $\begin{array}{l}\text { Closed } \\
\text { fixed }\end{array}$ & $\begin{array}{l}\text { - applicable to non-water } \\
\text { sorbates } \\
\text { - power and capacity are } \\
\text { interlinked }\end{array}$ & $\begin{array}{l}\text { - increased vapour } \\
\text { pressure and density } \\
\text { - no fouling of sorbent } \\
\text { - no sorbent transport } \\
\text { required }\end{array}$ & $\begin{array}{l}\text { - operates at sub } \\
\text { atmospheric pressure } \\
\text { - requires condenser and } \\
\text { evaporator } \\
\text { - sensitive to non- } \\
\text { condensing gases } \\
\text { - requires sorbate } \\
\text { storage } \\
\text { - dynamic process } \\
\text { parameters } \\
\text { temperature and power } \\
\text { - batch wise desorption } \\
\text { and sorption } \\
\text { - high parasitic heat } \\
\text { capacity } \\
\text { - high pressure drop for } \\
\text { air based heat } \\
\text { exchange } \\
\text { - reduced GTLs } \\
\text { - max discharge to } \\
\text { output temperature } \\
\text { - low heat transfer } \\
\text { between sorbent and } \\
\text { HX with solids }\end{array}$ \\
\hline $\begin{array}{l}\text { Closed } \\
\text { transported }\end{array}$ & $\begin{array}{l}\text { - applicable to non-water } \\
\text { sorbates } \\
\text { - separate scaling of } \\
\text { power and capacity }\end{array}$ & $\begin{array}{l}\text { - increased vapour } \\
\text { pressure and density } \\
\text { - no external fouling } \\
\text { - } \text { steady state process } \\
\text { - continuous desorption } \\
\text { and sorption } \\
\text { - capable of single pass } \\
\text { and counter flow } \\
\text { - maximum GTLs } \\
\text { - discharge to minimum } \\
\text { input temperature }\end{array}$ & $\begin{array}{l}\text { - operates at sub } \\
\text { - } \text { requires condenser and } \\
\text { evaporator } \\
\text { - sensitive to non- } \\
\text { condensing gases } \\
\text { - requires sorbate } \\
\text { storage } \\
\text { - Increase in complexity, } \\
\text { storage vessels and } \\
\text { means of transport } \\
\text { - low heat transfer } \\
\text { between sorbent and } \\
\text { HX with solids }\end{array}$ \\
\hline
\end{tabular}

3 Examples of systems from literature

In the following section, examples of systems reported in scientific literature of all four basic sorption processes are taken and compared based on temperature effectiveness (TE). The comparison does not include reference to power or energy density for reasons specified in the introduction.

\subsection{Open fixed}

There are many institutes working on open systems with fixed bed reactors. Segmented vessels with shallow beds for reduced pressure drop, improved thermal response and reduced release of heat to bulk sorbent due to material thermal capacity are looked into [44, 58-60]. In general, air 
serves as both heat and sorbate transport medium and building integration via forced air ventilation is focused on. This is due to the potentially higher vapour pressure in the air released from buildings. Nevertheless, this approach does not introduce external heat to the building but only more thoroughly recovers heat from the building. In the following examples, remarks on claimed volumetric energy storage density and volumetric charge and discharge power density are provided in the discussion, but are not the focus of comparison.

At the University of Lyon, France, in collaboration with the University of Savoie, France, an open fixed bed system has been designed consisting of two drum-like containers, in a segmented fixed bed storage design. The sorbents zeolite $\mathrm{Na}-\mathrm{X}$ [58] and zeolite 13X [45] are tested in the setup. The applied desorption temperatures is $180^{\circ} \mathrm{C}$. This is a challenging temperature to reach apart from electric resistive heating and represents a difficulty in all zeolite based systems. The ambient temperature and relative humidity in turn are not specified in the respective reporting. If $25^{\circ} \mathrm{C}$ and $55 \% \mathrm{RH}$ is taken as average temperature and humidity values for Lyon, equalling to a WBT of $15{ }^{\circ} \mathrm{C}$, the $\mathrm{GTL}_{\mathrm{D}}$ is $165 \mathrm{~K}$. Sorption is performed at an air temperature of $20^{\circ} \mathrm{C}$ and $70 \% \mathrm{RH}$, equal to a WBT of $14{ }^{\circ} \mathrm{C}$. This is a high WBT even for air recovery in buildings, considering that the sorption process takes place in the cold season when the indoor relative humidity is typically low in the range of $30-50 \%$. The reported output temperature is approximately $57{ }^{\circ} \mathrm{C}$ as shown in figure 3 right, resulting in a GTLs of $43 \mathrm{~K}$.
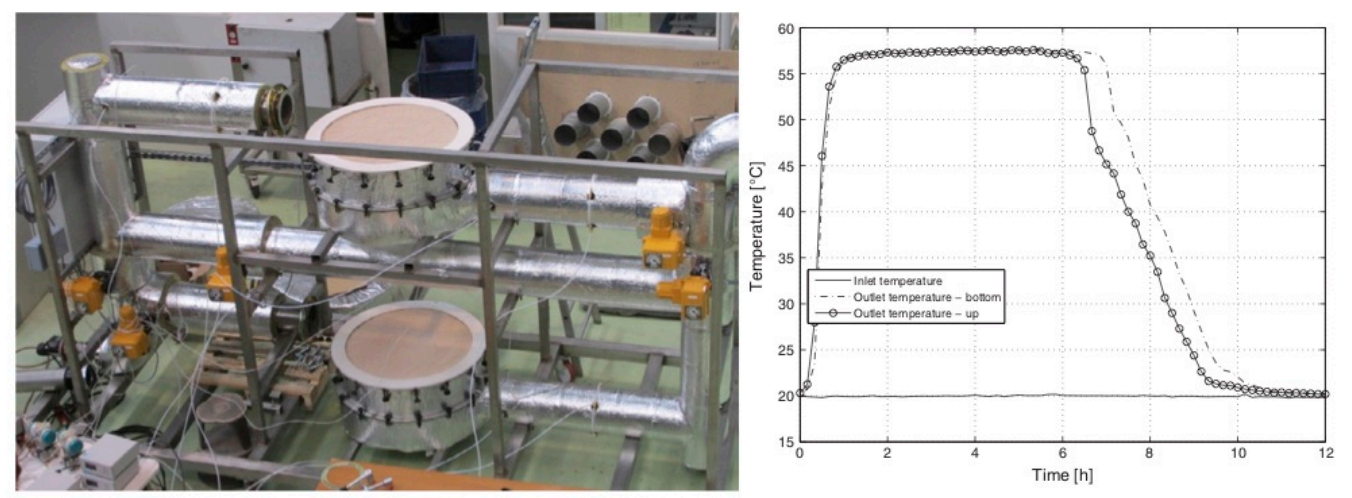

Figure 3: Left: Prototype open fixed bed system with dual storage compartments operated with zeolite Na-X and zeolite 13X. Right: Output temperature vs. time curve of a sorption test with zeolite Na-X from the University of Lyon, France [58].

A material specific volumetric energy density of approximately $85 \mathrm{kWh} / \mathrm{m}^{3}$ is reported, noting that a reduction in desorption temperature to $120^{\circ} \mathrm{C}$ and thus $105 \mathrm{~K} \mathrm{GTL}$ leads to a decline in energy density to $60 \mathrm{kWh} / \mathrm{m}^{3}$. This points out the substantial effect that charging $G T L_{D}$ has on storage density. Further substantial decline in both energy density and kinetics would have to be accounted for if the WBT is adapted to more realistic operation conditions. Due to the shallow bed design, a steep temperature drop is encountered at breakthrough temperature. The sorbent cannot be discharged beyond this temperature threshold. With zeolite $13 \mathrm{X}$ at identical desorption and sorption conditions as followed for zeolite $\mathrm{Na}-\mathrm{X}$, GTLs was $44 \mathrm{~K}$ and at $20{ }^{\circ} \mathrm{C}$ but lower WBT of $9^{\circ} \mathrm{C}, \mathrm{GTL}_{s}$ of $37 \mathrm{~K}$ was reached. This shows that $\mathrm{GTL}$ s is affected by the WBT.

A tray type segmented fixed bed reactor was reported by Michel et al. from PROMES-CNRS, France [61], based on the solid sorption salt pair $\mathrm{SrBr}_{2}$ and water. Segmentation is followed in order to reduce pressure drop. Shallow beds are designed and operated in parallel. The applied GTL $L_{D}$ in desorption is approximately $62 \mathrm{~K}$ with a desorption temperature of $82{ }^{\circ} \mathrm{C}$ and a WBT of $20^{\circ} \mathrm{C}$. These desorption settings are more realistic for a direct solar heated or heat pump assisted desorption process. The resulting GTLs is $19 \mathrm{~K}$ with an output temperature of approximately $25^{\circ} \mathrm{C}$ and a WBT of $6{ }^{\circ} \mathrm{C}$. In figure 4 bottom, the operation conditions are displayed in a ClausiusClapeyron diagram. 

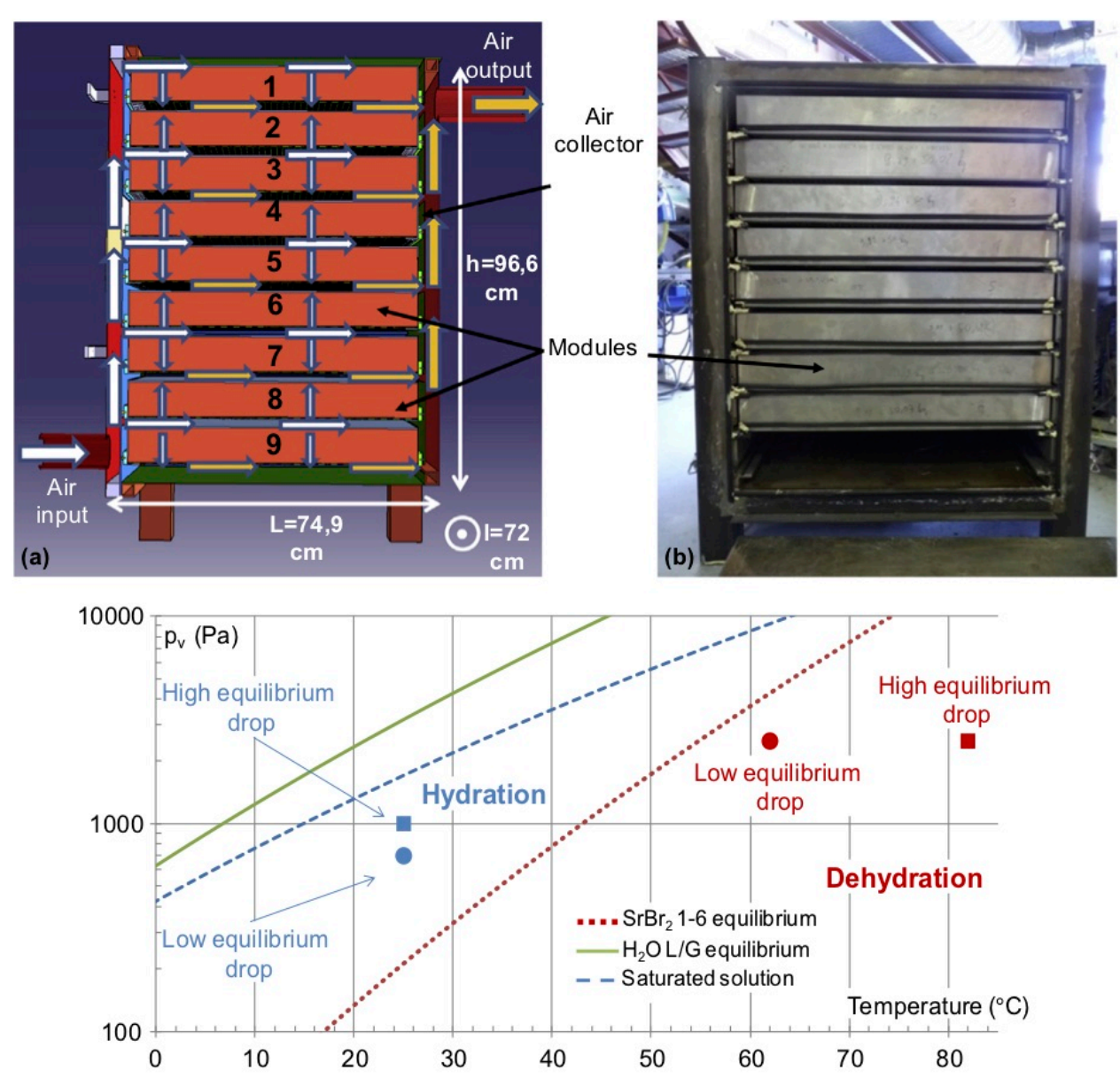

Figure 4: Top Left: Illustration of the reactor prototype including dimensions and air flow path. Top right: Picture of the installed trays. Bottom: Experimental operating conditions for the reactor prototype based on the $\mathrm{SrBr}, 1-6 \mathrm{H} 2 \mathrm{O}$ reaction, in a Clausius-Clapeyron diagram [61].

In the frame of the SolSpaces project an open fixed bed sorption storage system was developed at ITW Stuttgart, Germany [42]. The employed working pair is zeolite 13XBF and water. Desorption temperature is reported to be $180^{\circ} \mathrm{C}$ at 10 mbar partial water vapour pressure equal to a WBT of $8^{\circ} \mathrm{C}$, thus a $\mathrm{GTL}_{\mathrm{D}}$ of $172 \mathrm{~K}$ is applied. In sorption, air is supplied at approximately $26{ }^{\circ} \mathrm{C}$ and relative humidity of $38 \%$ equal to a WBT of $10^{\circ} \mathrm{C}$. The resulting GTLs is approximately $42 \mathrm{~K}$ if an average output temperature of $52^{\circ} \mathrm{C}$ is taken, as visible in the temperature profile in figure 5 bottom right. This is an example where the thermal testing conditions are substantially out of the domestic heat storage application scope, especially since the WBT in desorption is lower than in sorption. 

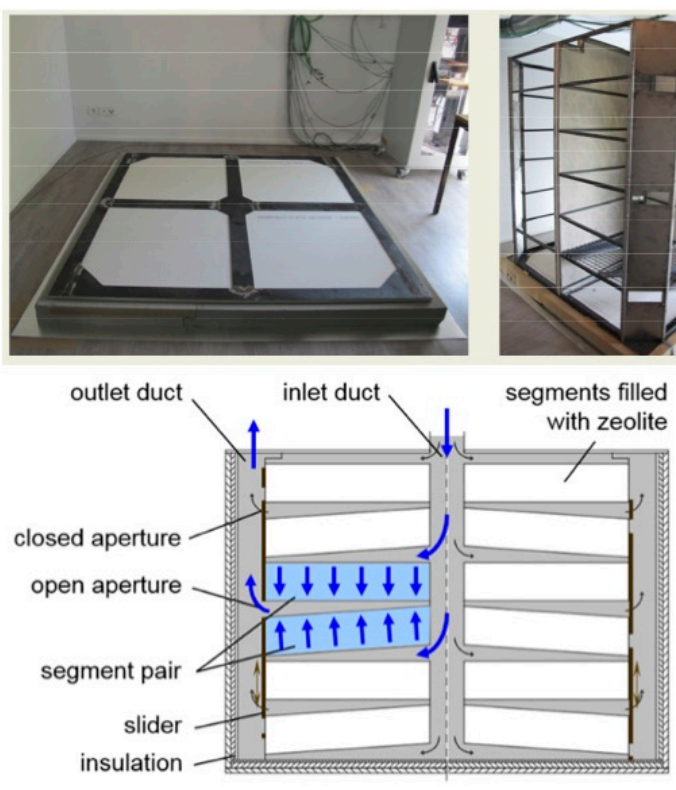
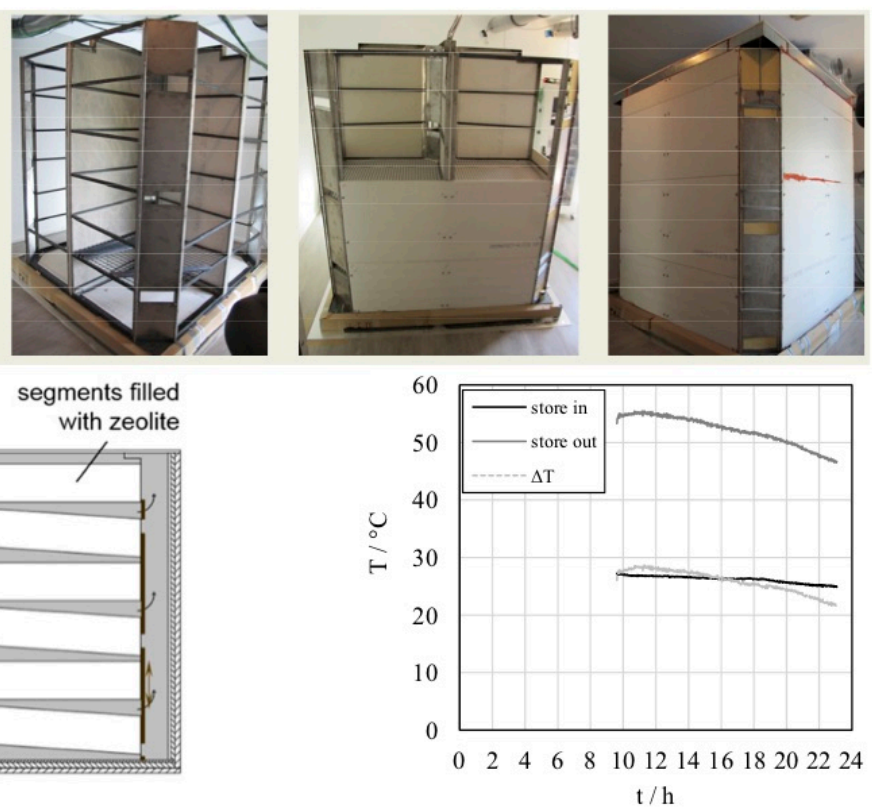

Figure 5: Top: Pictures of the system in construction. Bottom left: Vertical cut through the vessel with air flow indication. Bottom right: Temperature profile in sorption of the SolSpaces project demonstrator. [42].

At Shanghai Jiao Tong University, China, work is performed on a segmented packed bed storage, operating on the solid sorption composite material activated alumina and lithium chloride [62].

Contrary to the previous described setups, storage segments are installed vertically and in series. Desorption temperature is $110^{\circ} \mathrm{C}$ whereby the $\mathrm{GTL}_{\mathrm{D}}$ is not clear, since no partial vapour pressure is indicated. Under the assumption of $25^{\circ} \mathrm{C}$ and $55 \% \mathrm{RH}$, equal to a WBT of $15^{\circ} \mathrm{C}, \mathrm{GTL}$ is $95 \mathrm{~K}$. Sorption is performed at an air temperature of $20^{\circ} \mathrm{C}$ and relative humidity of $60 \% \mathrm{RH}, 70 \% \mathrm{RH}$ and $80 \% \mathrm{RH}$ with WBT $12{ }^{\circ} \mathrm{C}, 14.4^{\circ} \mathrm{C}$ and $16.5^{\circ} \mathrm{C}$ respectively. These values are substantially higher than available for building heating application. In the report, it is noted that maximum discharge temperature depends on the relative humidity, which is clear, since the respective WBT changes, while the GTLs of $27 \mathrm{~K}, 27.3 \mathrm{~K}$ and $28 \mathrm{~K}$ respectively remains relatively constant, as discussed in the introduction. Figure 6 bottom right, shows the sorption results under the varying relative humidity. It is also noted that the energy density of segment 1 , approximately $230 \mathrm{kWh} / \mathrm{m} 3$, is greater than segment 2, which has approximately $130 \mathrm{kWh} / \mathrm{m} 3$. The explanation to this phenomenon can be seen in the temperature profile, whereby the final discharge temperature of segment 1 is lower than that of segment 2. Consequently, segment 1 has a greater vapour uptake due to the lower temperature. Segment 2 is not able to reach the equal state of discharge since thermal breakthrough temperature prohibits further operation. This is a good example of the benefit of serial connection of storage segments for increased storage capacity. 


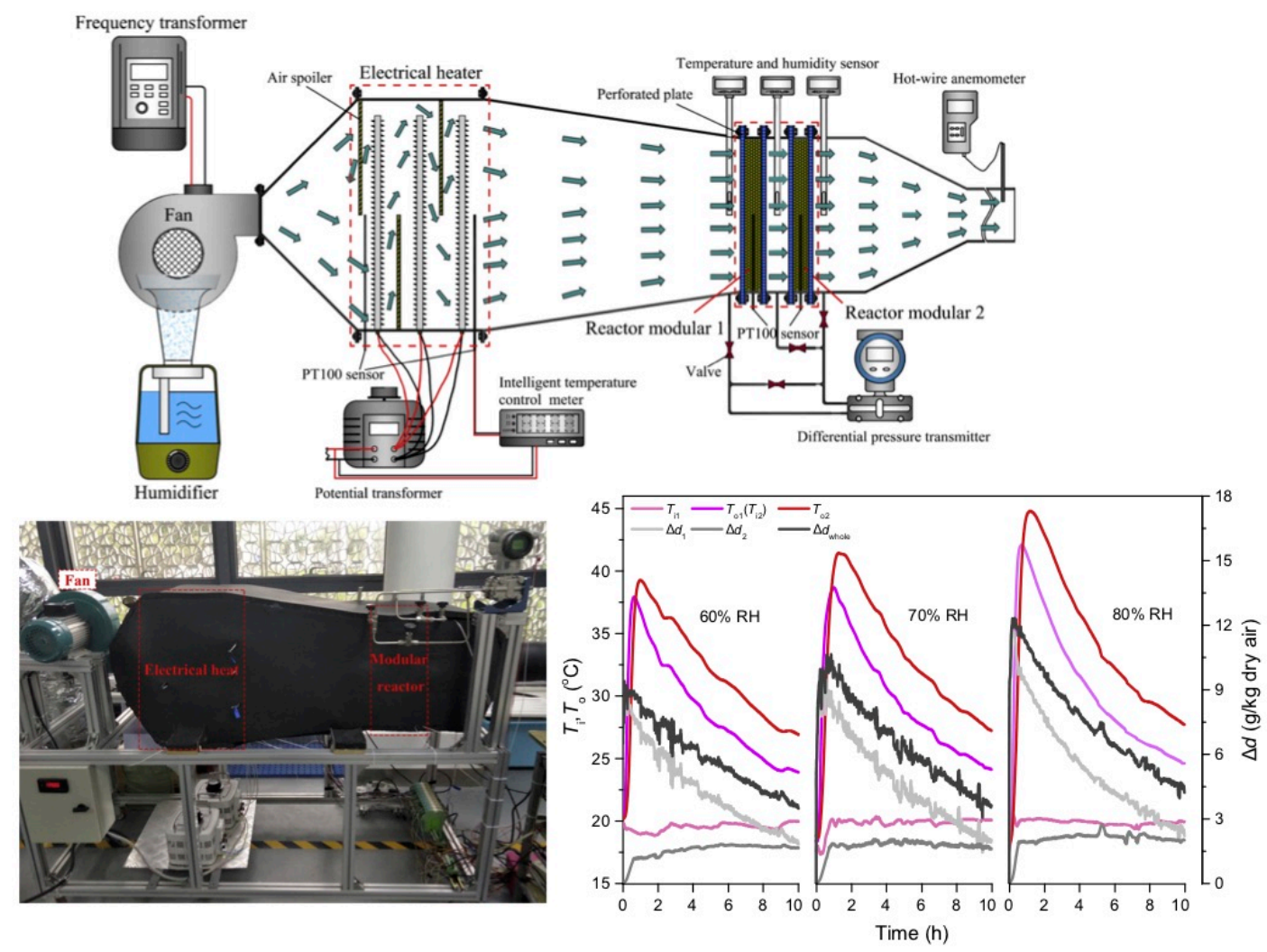

Figure 6: Top: Schematics of the test bench setup with air supply, humidifier and heater, preceding the dual modules connected in series. Bottom left: Picture of the insulated setup. Bottom right: sorption temperature and humidity results in respect to $60 \% \mathrm{RH}, 70 \% \mathrm{RH}$ and $80 \% \mathrm{RH}$ at $20{ }^{\circ} \mathrm{C}$ supply air temperature of the Shanghai Jiao Tong University demonstrator [62].

At the University of Nottingham, England, an alternative pipe shaped sorbent storage system design is followed and operated with the solid sorbent composite material vermiculite / calcium chloride as well as tested with the sorbent zeolite 13X [63]. The storage system is segmented into three tube-type vessels holding a perforated inner tube with sorbent packed between the inner and the outer tube. Air is supplied to the inner tube where it spreads to the sorbent and is released at the top of the outer tube to be supplied to the building. Desorption is performed at $80^{\circ} \mathrm{C}$ with a vapour pressure of $0.18 \mathrm{mbar}$, equal to a WBT of $-40^{\circ} \mathrm{C}$, thus desorption is performed at a GTL of $120 \mathrm{~K}$. Sorption is carried out at $20^{\circ} \mathrm{C}$ input temperature and 21.6 mbar vapour pressure, resulting in a WBT of $19^{\circ} \mathrm{C}$. The output temperature is approximately $40^{\circ} \mathrm{C}$, as seen in figure 7 right, thus $\mathrm{GTL}_{s}$ is about $21 \mathrm{~K}$. It must be noted that these operating temperatures strongly violate the application scope, with the WBT in desorption substantially lower than in sorption. In the report it is stated that intermittent sorption of the storage does not affect sorption temperature. This may be due to the low air penetration depth coming from the tube type design, leading to a homogeneous discharge. It may be misleading to assume similar behaviour at larger bulk scale. 

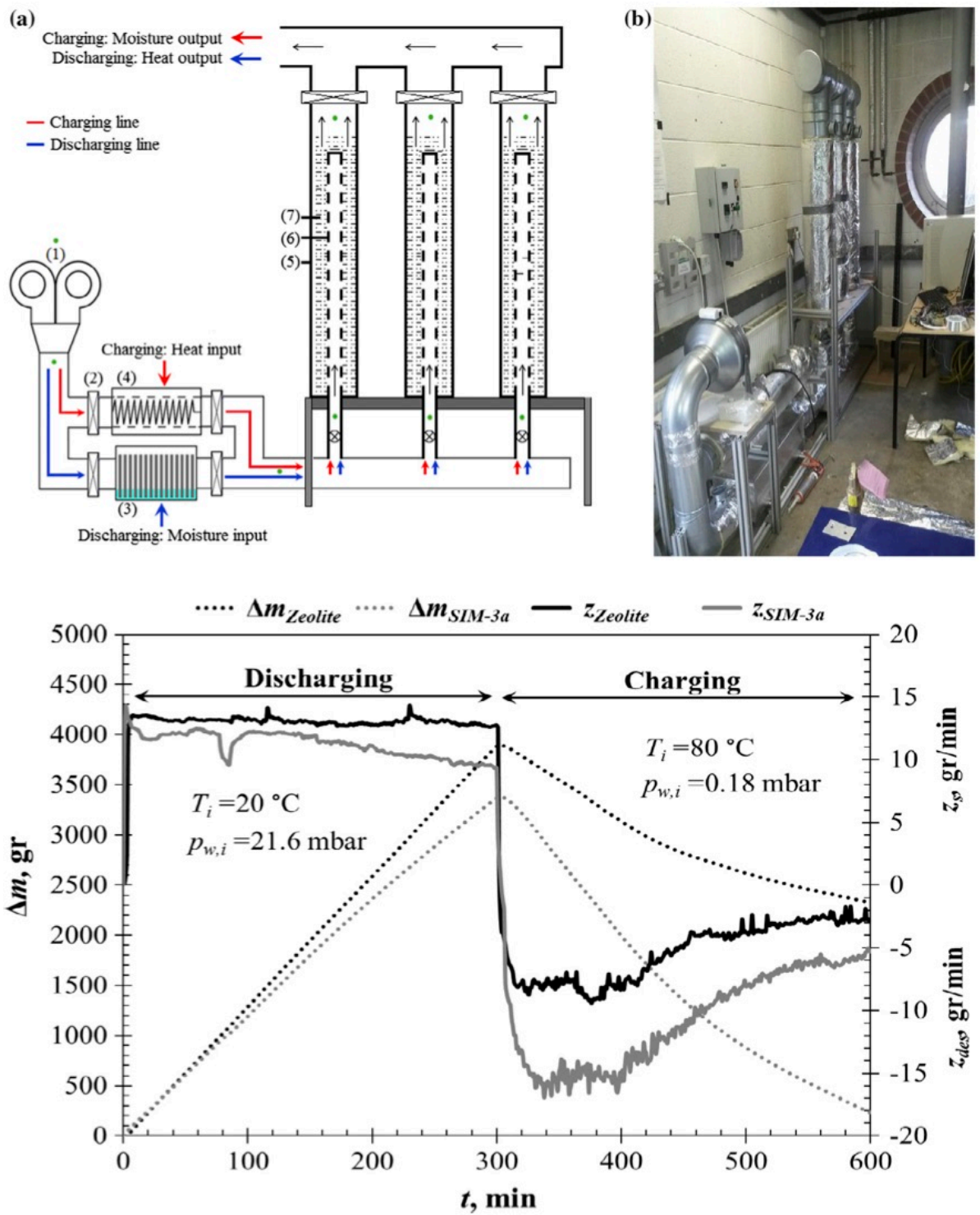

Figure 7: Top left: Schematics of the testing rig, illustrating both desorption and sorption processes. Top right: Picture of the test setup. Bottom: Mass change and sorption/desorption rates of the testing rig operated with zeolite and SIM-3a in sorption and desorption cycles with operating temperatures indicated [63].

At the Eindhoven University of Technology in collaboration with ECN in the Netherlands, a segmented fixed bed system consisting of four tanks with a volume of $62.5 \mathrm{~L}$ each was developed and tested with the working pair zeolite and water [60]. The material is desorbed at a temperature of $190{ }^{\circ} \mathrm{C}$ whereby relative humidity is not given. Assuming a WBT of $15^{\circ} \mathrm{C}$ the GTLD is $175 \mathrm{~K}$. Sorption temperature is $10^{\circ} \mathrm{C}$ with a relative humidity of $90 \%$ resulting in a WBT of $8{ }^{\circ} \mathrm{C}$. Output temperature is $28^{\circ} \mathrm{C}$, whereby a GTLs of $20 \mathrm{~K}$ is reached with an average material specific energy density of $198 \mathrm{kWh} / \mathrm{m} 3$. Figure 8 shows both the system and operation results. An adjustment to application specific conditions in desorption would again result in substantial reduction of energy density. 

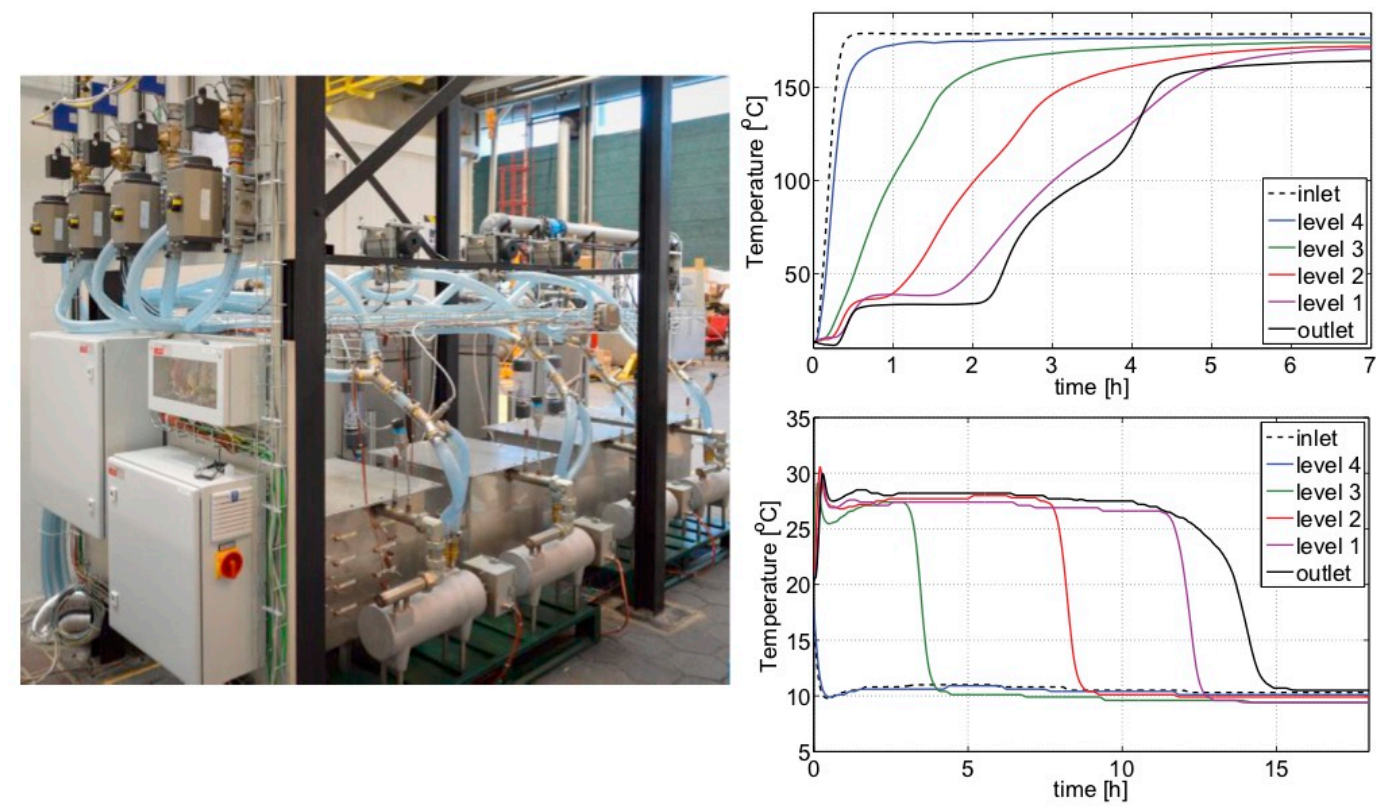

Figure 8: Left: Picture of the demonstrator setup. Right top: temperature profile in desorption. Right bottom: Temperature profile in absorption [60].

From the presented demonstration systems it can be seen that the open fixed bed approach leads to substantially lower $\mathrm{GTL}_{s}$ in sorption compared to the required $G T L_{D}$ in desorption. Low temperature output and reduced energy density are the result. This is due to the high turnover of air with low water vapour partial pressure during discharge and the significant thermal capacity of the sorbent. Further GTLs reduction comes from mixing of heat streams from sorbent at varying state of charge and it is clear that the system capacity is highly dependent on the thermal breakthrough temperature.

\subsection{Open transported}

At ITW University Stuttgart, Germany in collaboration with several other German Institutes [38, 6466], research is performed on open transported system concepts using the sorbent zeolite as well as salt impregnated Zeolites. As with the open and fixed systems discussed, this concept bases on the integration into the building forced air ventilation. A double stage sorption process is followed, whereby the cool moist air initially flows through the pre-reactor and then through the main reactor. In this way a two stage type counter flow is reached and discharge to below the output temperature threshold is possible since the pre-reactor is not bound to the output temperature threshold. Greater discharge is thus possible and higher storage capacity is reached. Nevertheless, due to the cross flow approach, GTLs at different state of charge is still mixed and consequently maximum temperature gain cannot be reached. Desorption is performed at $180^{\circ} \mathrm{C}$ and $10 \mathrm{mbar}$ vapour pressure equalling to a WBT of $7^{\circ} \mathrm{C}$ and $\mathrm{GTL}_{D}$ is $173 \mathrm{~K}$. Sorption is carried out at an air temperature of $28^{\circ} \mathrm{C}$ and 15 mbar with WBT equal to $13^{\circ} \mathrm{C}$. These operating conditions are again out of scope for the domestic heat storage application and the WBT in sorption is greater than in desorption. The output temperature after the pre- reactor is approximately $40{ }^{\circ} \mathrm{C}$ reaching a $\mathrm{GTL} s$ of $27 \mathrm{~K}$ and the temperature after the main reactor is $63^{\circ} \mathrm{C}$ with a GTLs of $50 \mathrm{~K}$. Notable in this system approach is the steady state process through sorbent transport and thus steady state output temperatures attributed to the transported system approach.

Work on open transported systems is also performed at the University of Mons, Belgium in collaboration with several other European Universities, within the SOTHERCO projects $[67,68]$. Varying concepts are considered with either a vertically positioned moving bed with horizontal air flow or a horizontal circular moving bed reactor with vertical air flow. Again, due to the cross flow approach in both concepts, GTLs at different state of charge is mixed and thus it is expected that 
maximum temperature cannot be reached. The open transported system example given shows that greater discharge and higher output GTLs can be reached with transported systems compared to open and fixed systems.

\subsection{Closed fixed}

The Netherlands organisation for Applied Scientific Research TNO has designed a zeolite 5A based closed sorption system [69].
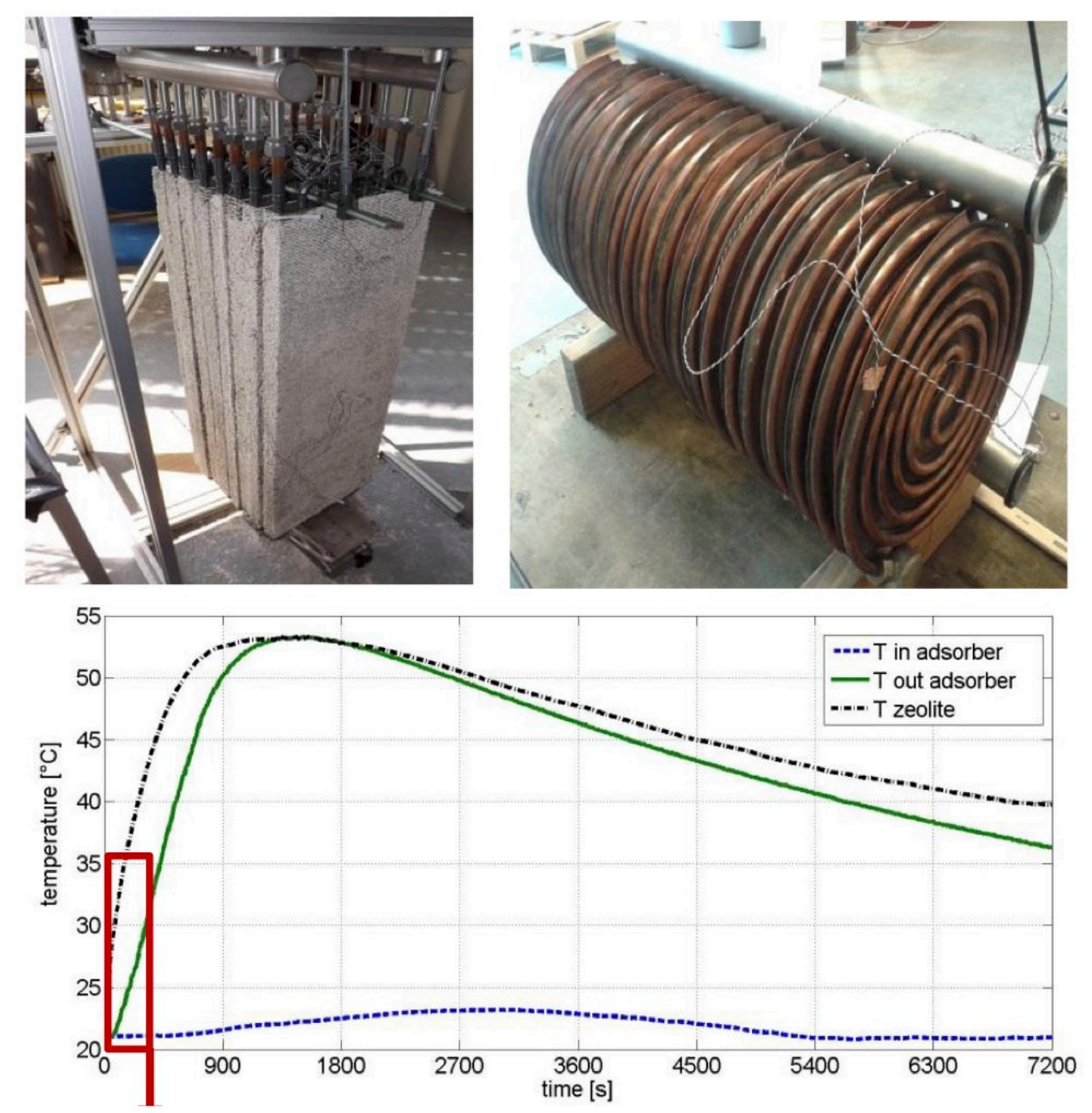

Figure 9: Top left: Picture of the sorber / desorber unit. Top right: Picture of the evaporator / condenser unit. Bottom: Operating result in sorption of the TNO designed zeolite $5 A$ based closed sorption system [69].

The setup consists of a sorber / desorber unit with the sorbent adhered to the heat exchanger and an evaporator / condenser unit consisting of several trays for water suspension with underlined tube heat exchanger. The system is desorbed at $103^{\circ} \mathrm{C}$ and $20^{\circ} \mathrm{C}$ condenser temperature, resulting in a GTL of $83 \mathrm{~K}$ and sorption is performed at $20^{\circ} \mathrm{C}$ input heat transfer fluid (HTF) temperature at an evaporator temperature of $15^{\circ} \mathrm{C}$. Maximum HTF output temperature is $53^{\circ} \mathrm{C}$ resulting in a maximum GTL of $38 \mathrm{~K}$ and an average $\mathrm{GTL}_{s}$ of about $30 \mathrm{~K}$. Figure 9 shows results from the sorption process. These testing temperatures are within realistic application conditions. 
At AEE Intec, Austria, work is done on the design of a closed fixed bed sorption heat storage system for domestic application [48]. The system consists of a vessel type containment filled with zeolite 13XBF with integrated heat exchanger for optimised heat transport as well as separate heat and mass exchanger serving as condenser and evaporator connected to a vessel for the liquid sorbate storage. Figure 10 shows the schematics as well as the extensive heat exchanger for the sorbent tank. Desorption is performed at $180^{\circ} \mathrm{C}$ and $17^{\circ} \mathrm{C}$ condensation temperature, consequently resulting in a GTL $L_{D}$ of $163 \mathrm{~K}$. In sorption, the condensation temperature is set to $20{ }^{\circ} \mathrm{C}$ and the discharge temperature is $45^{\circ} \mathrm{C}$ thus reaching a GTLs of $25 \mathrm{~K}$. These temperatures are outside of the domestic heating application conditions. A lower condensation temperature than evaporation temperature is generally not realistic.
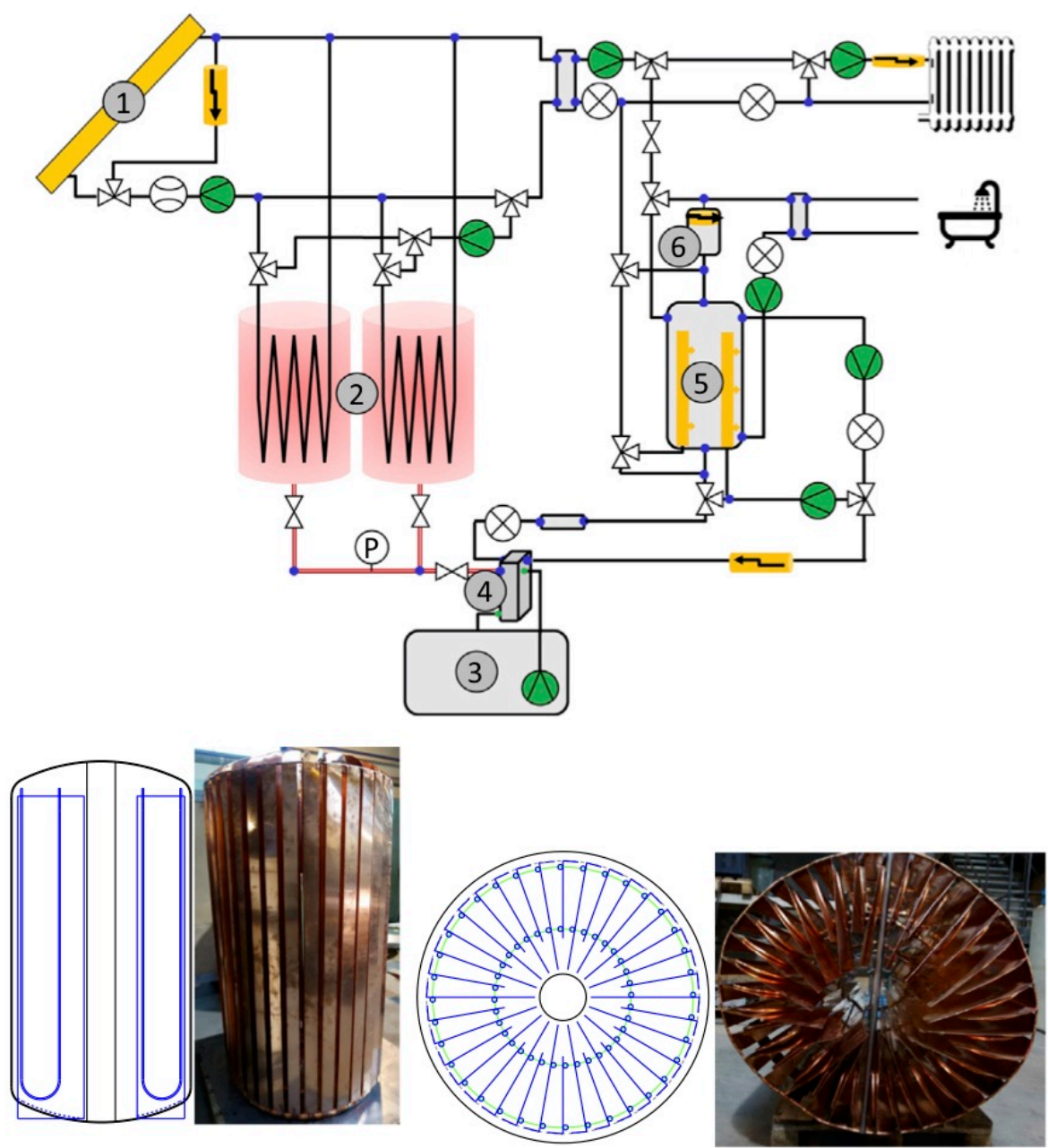

Figure 10: Top: Schematics of the AEE Intec closed fixed system. Bottom: Picture of the fixed bed integrated heat exchanger [48].

Work is performed on a closed fixed bed sorption heat storage for domestic application at TNO in the Netherlands in the frame of the MERITS project based on sodium sulphide [53]. The demonstrator consists of several storage vessels incorporating heat and mass exchangers with integrated solid sorbent, as well as heat and mass exchangers for evaporation and condensation of sorbate. Figure 11 shows the proposed system schematics. The working pair is the solid sorbent $\mathrm{Na}_{2} \mathrm{~S}$ and water as sorbate. Required desorption temperature is stated to be $80{ }^{\circ} \mathrm{C}$ at a condensing temperature of $20^{\circ} \mathrm{C}$, hence effecting a GTL $L_{D}$ of $60 \mathrm{~K}$. In sorption an output temperature of $65^{\circ} \mathrm{C}$ and evaporator temperature of $10^{\circ} \mathrm{C}$ is proposed, suggesting a GTLs of $55 \mathrm{~K}$. Nevertheless, to 
date there are no measured results published. It is expected that operational results will deviate substantially due to the mentioned system design limitations.

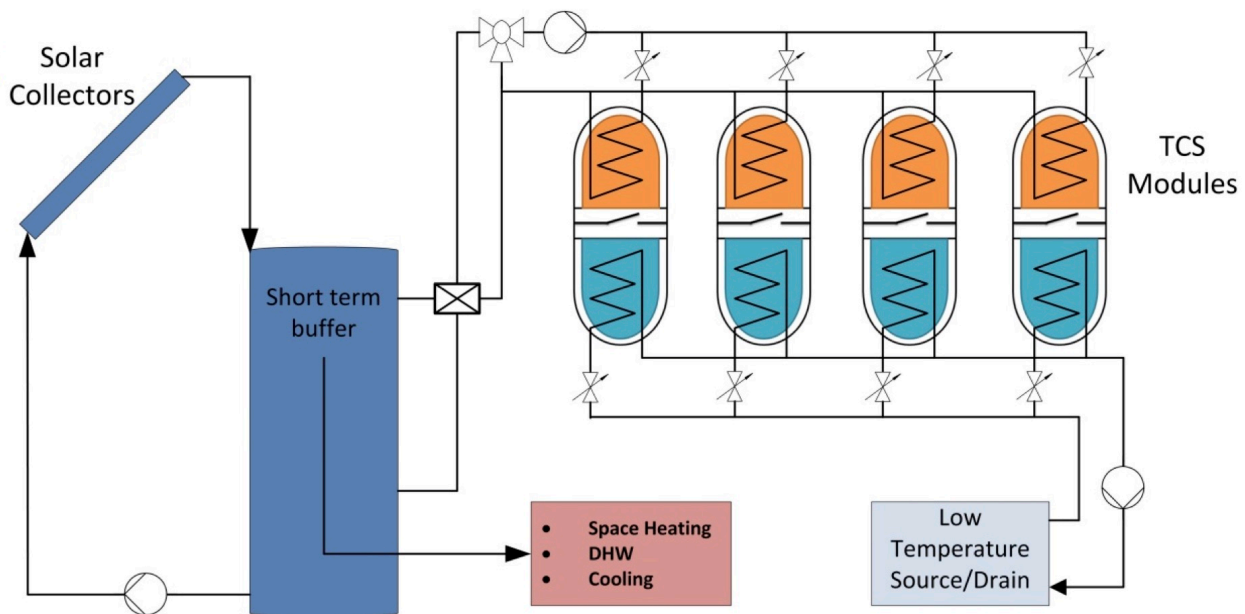

Figure 11: Schematics of the Merits system [53].

Palomba et al. from the CNR, Messina, Italy, present a system operating with the working pair AQSOA FAM Z02 / water able to supply heat and cold [70]. Figure 12 shows the schematics and operating results. Desorption temperature is $90^{\circ} \mathrm{C}$ at $30^{\circ} \mathrm{C}$ condensation temperature, a realistic temperature setting, equalling to $a G_{T L}$ of $60 \mathrm{~K}$ and evaporation temperature is $10^{\circ} \mathrm{C}$ with a sorption temperature of $35^{\circ} \mathrm{C}$ and GTLs of $25 \mathrm{~K}$. These temperatures settings are well fitting to the building heating application. The condensation temperature in desorption is $20 \mathrm{~K}$ greater than the evaporation temperature in sorption. 

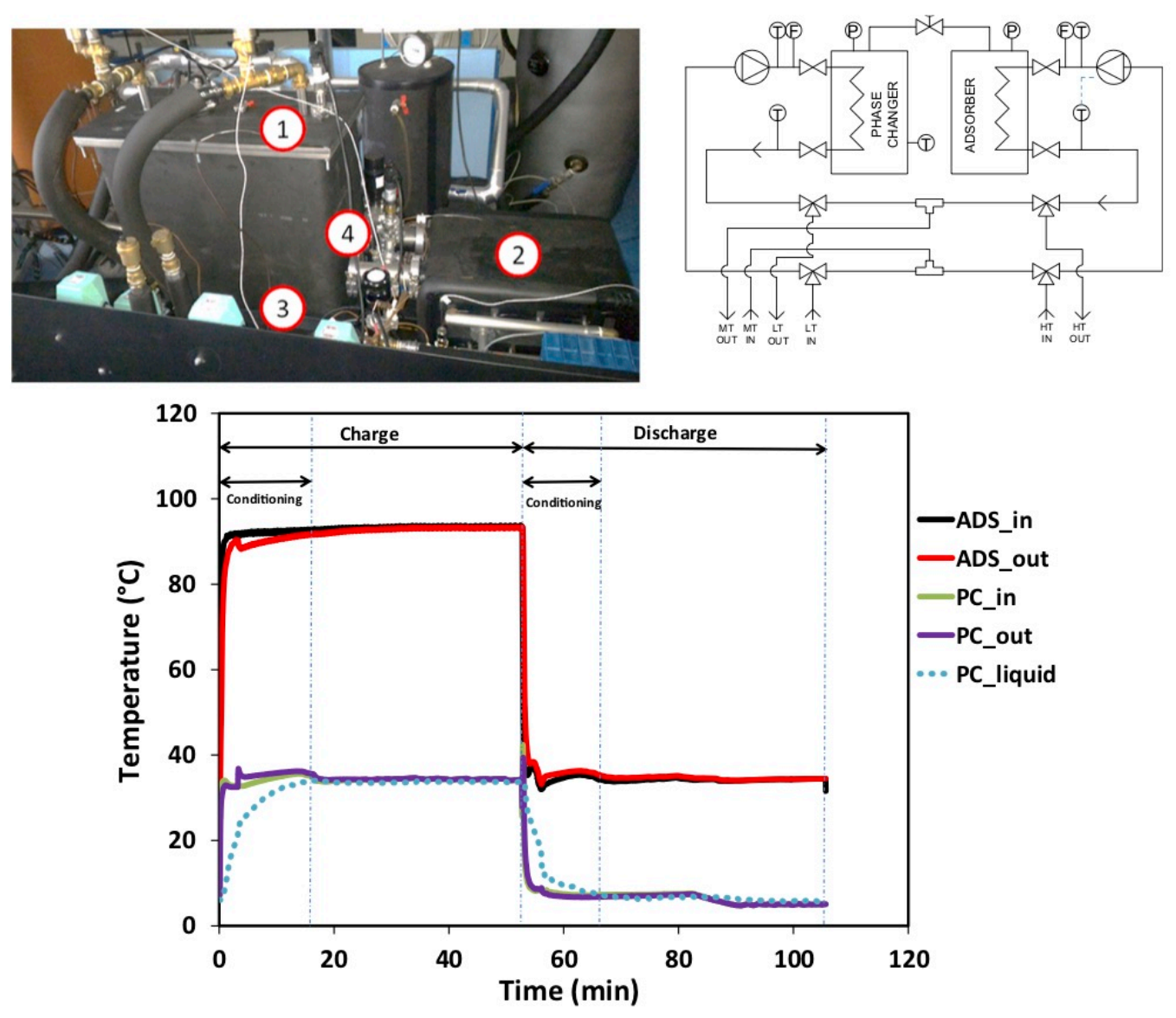

Figure 12: Top left: Picture of the University of Messina setup with sorber / desorpber at position 1 and condenser / evaporator at position 2. Top right: Schematics of the test setup. Right:

Temperature profiles in desorption and sorption [70].

On the same setup as Palomba, shown in figure 12, in collaboration with the Boreskov Institute of Catalysis and the Novosibirik State University, Russia, work is done on the composite material LiCl / vermiculite [71]. Initial system demonstrator scale tests were also performed at $90{ }^{\circ} \mathrm{C}$ desorption and $30{ }^{\circ} \mathrm{C}$ condensation, resulting in a $G T L_{D}$ of $60 \mathrm{~K}$. As shown in figure 13 , in desorption, the evaporation temperature is approximately $12.5^{\circ} \mathrm{C}$ and the absorption temperature average taken from the initial 6 minutes is $37^{\circ} \mathrm{C}$, thus a $\mathrm{GTL}_{s}$ of $24.5 \mathrm{~K}$ is reached. From the time scale it is visible that this is still a small lab setup.
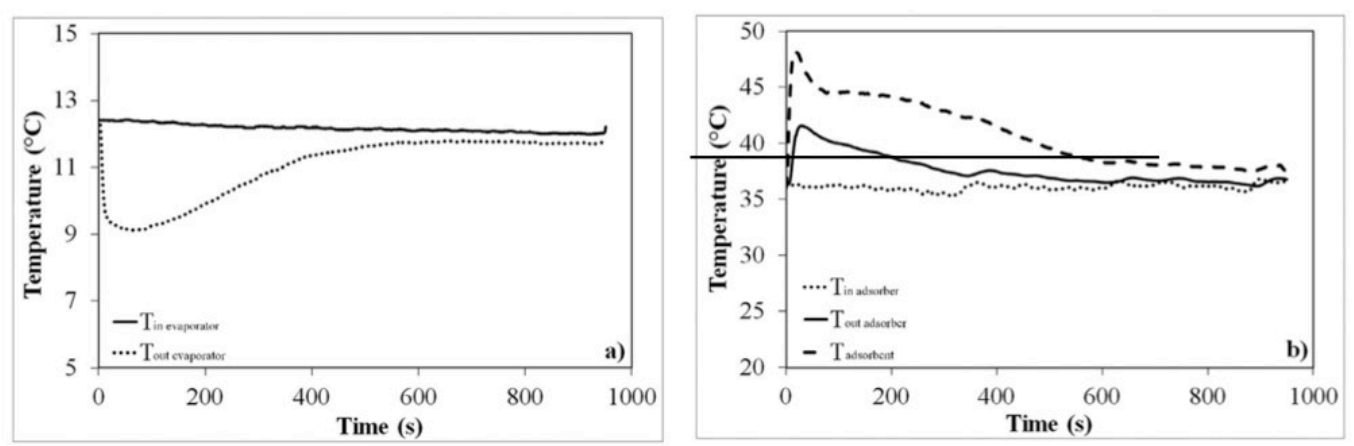

Figure 13: Operating diagram in sorption with LiCl / vermiculite composite. Right: Evaporator temperatures, Left: Absorber temperatures [71]. 
Zhao et al. report a fixed bed $\mathrm{LiCl}$ / expanded graphite and water working system from Shanghai Jiao Tong University, China [72]. The absorber / desorber consists of a large number of trays containing the $\mathrm{LiCl}$, with attached heat exchanger. Figure 14 shows the setup. Desorption is performed at $85{ }^{\circ} \mathrm{C}$ with $18{ }^{\circ} \mathrm{C}$ condensation temperature, requiring a GTL $L_{D}$ of $67 \mathrm{~K}$. Evaporation is performed at $18^{\circ} \mathrm{C}$, achieving an sorption temperature of $40^{\circ} \mathrm{C}$ and granting a GTLs of $22 \mathrm{~K}$. Figure 14 shows operating results of the demonstrator.

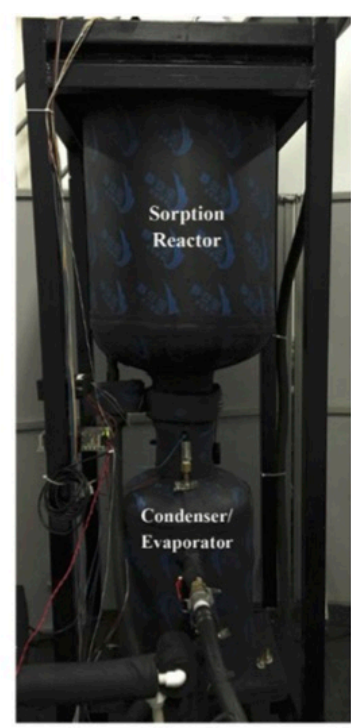

(a) Experimental prototype

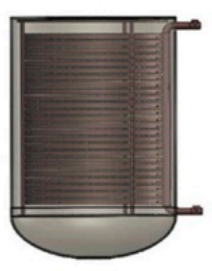

(b) Sorption reactor

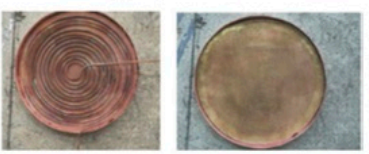

$\begin{array}{ll}\text { (c) Sorption unit } & \text { (d) Copper mesh }\end{array}$

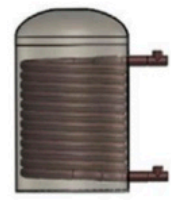

(e) Condenser/Evaporator

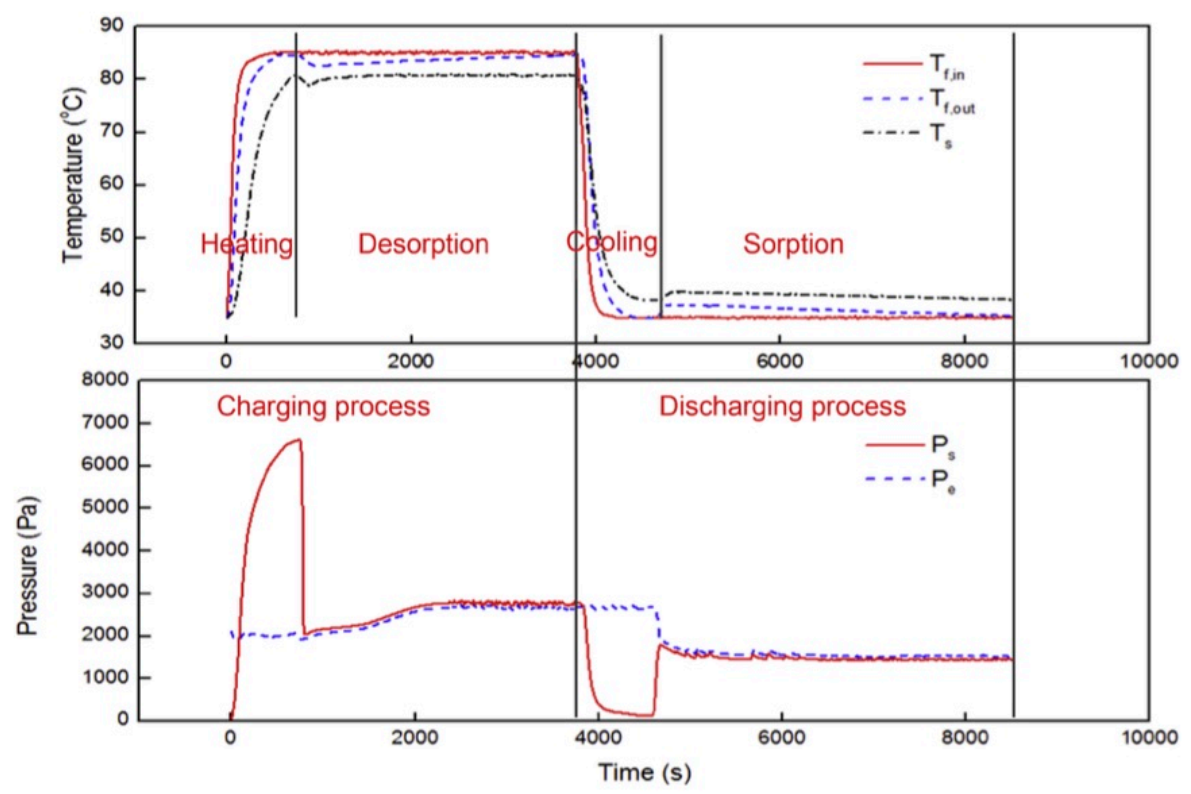

Figure 14: Top: Picture of the setup as well as the sorber / desorber and evaporator / condenser unit. Bottom: Operating results in desorption as well as sorption of the Shanghai Jiao Tong University demonstrator [72].

At the Institute of Refrigeration and Cryogenics, Shanghai Jiao Tong University, China in collaboration with Sir Joseph Swan Centre for Energy Research, UK [73] work is done on a closed fixed system based on the working pair $\mathrm{MnCl}_{2}-\mathrm{CaCl}_{2}-\mathrm{NH}_{3}$ where the sorbate is $\mathrm{NH}_{3}$. Figure 15 shows a picture of the setup, the theoretical $\mathrm{p}-\mathrm{T}$ diagram and operating results. On a theoretical basis, the $G T L_{D}$ is $55 \mathrm{~K}$ and the $\mathrm{GTL}_{s}$ is $50 \mathrm{~K}$, as shown in the $\mathrm{p}-\mathrm{T}$ diagram in figure 15 . In operation desorption was performed at a $157^{\circ} \mathrm{C}$ at a condensation temperature of $21^{\circ} \mathrm{C}$ resulting 
in a $G T L_{D}$ of $136 \mathrm{~K}$. Sorption was performed at an Evaporation temperature of $10.6{ }^{\circ} \mathrm{C}$ and the average temperature reached was $58^{\circ} \mathrm{C}$ thus achieving a $\mathrm{GTL}_{s}$ of $47.4 \mathrm{~K}$. Figure 15 shows the respective operation diagrams.
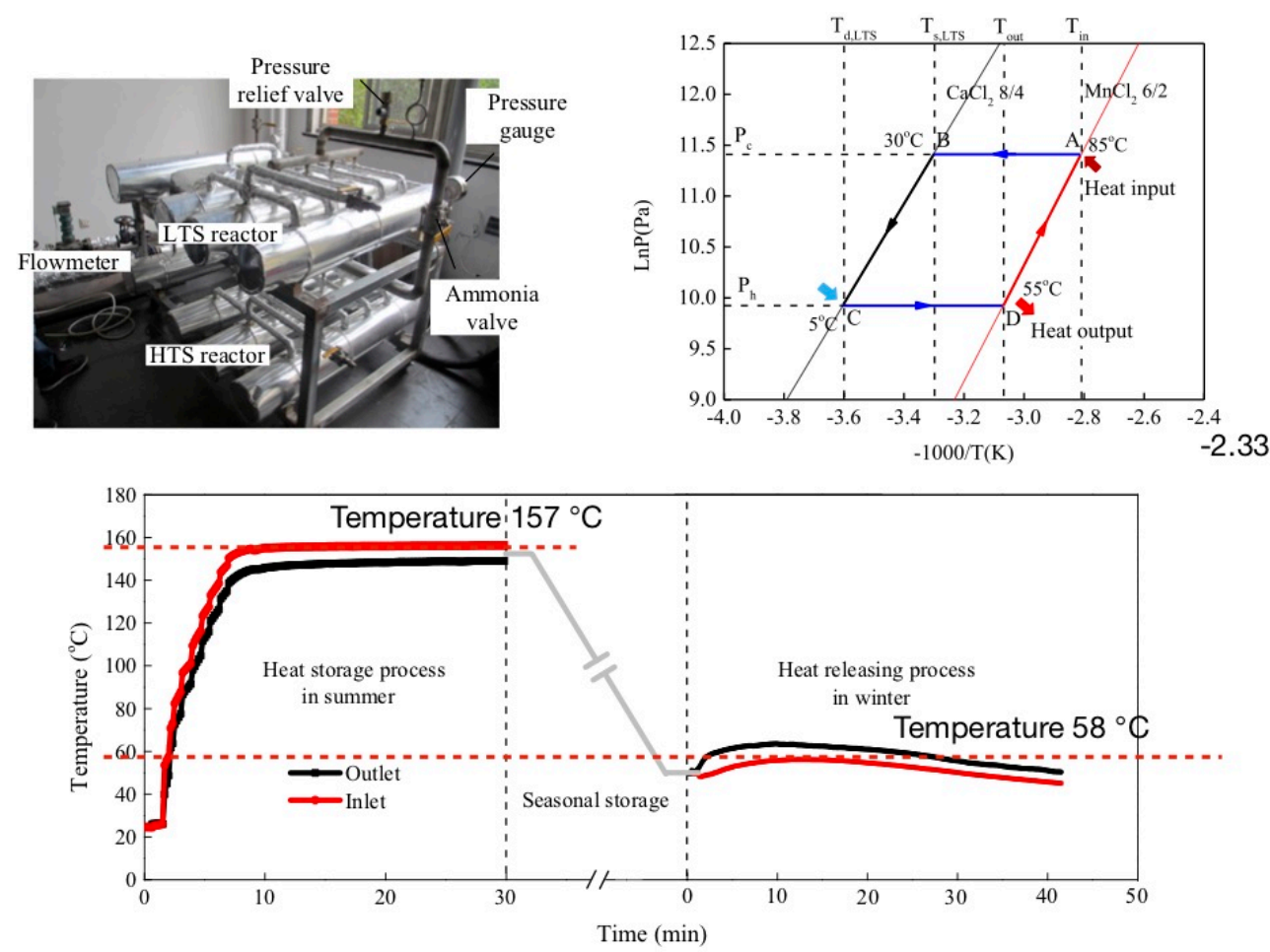

(a)

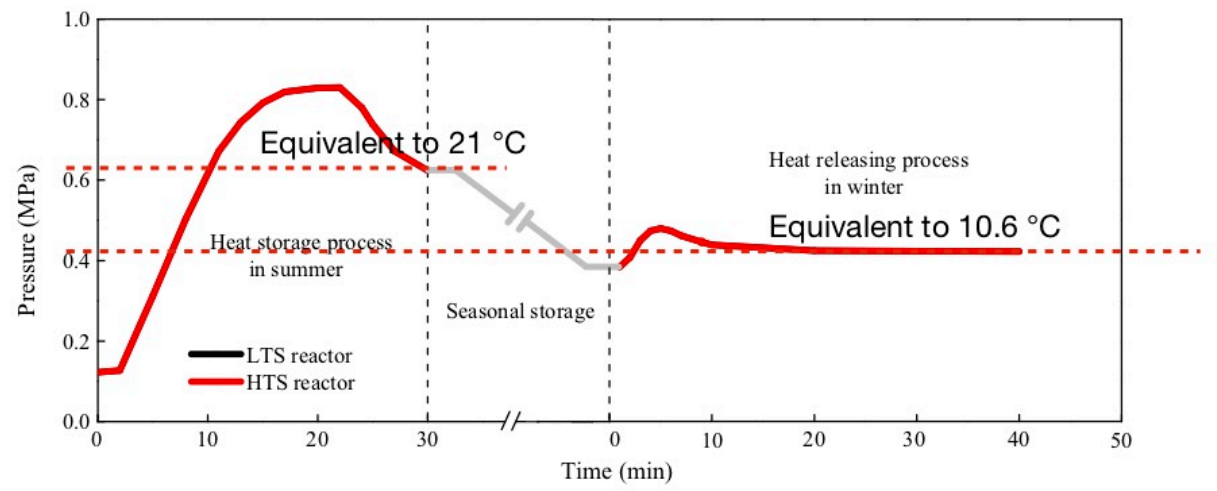

(b)

Figure 15: Top left: Picture of the test setup operating with the working pair $\mathrm{MnCl}_{2}-\mathrm{CaCl}_{2}-\mathrm{NH}_{3}$. Top right: $p-T$ diagram with the theoretical operating temperatures and pressures. Bottom: Diagrams of the desorption and sorption process, indicating temperature and pressure, red dotted lines are included for clarification [73].

Closed fixed systems are often employed for dual mode systems, able to supply both heat and cold [74] or operating on other sorbates than water such as $\mathrm{NH}_{3}[75,76]$. Yan et al. also proposes a system with $\mathrm{MnCl} 2$ and $\mathrm{NH} 3$, with GTLD of $154 \mathrm{~K}$ and GTLs of $35 \mathrm{~K}$ [75]. In general, closed fixed systems reach a higher GTLs due to the lack of air present in the sorbate transport.

\subsection{Closed transported}

At the research institute Empa in Switzerland, work is done on closed transported liquid sorption with aqueous sodium hydroxide [45]. The system consists of an absorber and desorber 
interconnected to a condenser and evaporator forming a HMX unit for sorbate vapour exchange and storage vessels for charged and discharged sorbent figure 16 shows the schematics as well as a picture of the setup. The heat and mass exchanger is designed so that that the sorbent is in counter flow to the HTF. In this approach, the sorbent final temperature in sorption is close to the HTF input temperature. In this way maximum sorbate uptake and maximum HTF output temperature is enabled through constant feed of charged sorbent reaching maximum GTL. Counterflow and single pass enable steady state process in both sorption and desorption.

Reported desorption temperature is $65^{\circ} \mathrm{C}$ at a condensation temperature of $10^{\circ} \mathrm{C}$ with a GTLD of $55 \mathrm{~K}$. In sorption an average GTLs of $23 \mathrm{~K}$ is achieved with $25^{\circ} \mathrm{C}$ evaporator temperature and $48^{\circ} \mathrm{C}$ absorber temperature. Again, these test settings must be criticised, since the evaporation temperature is greater than the condensation temperature.
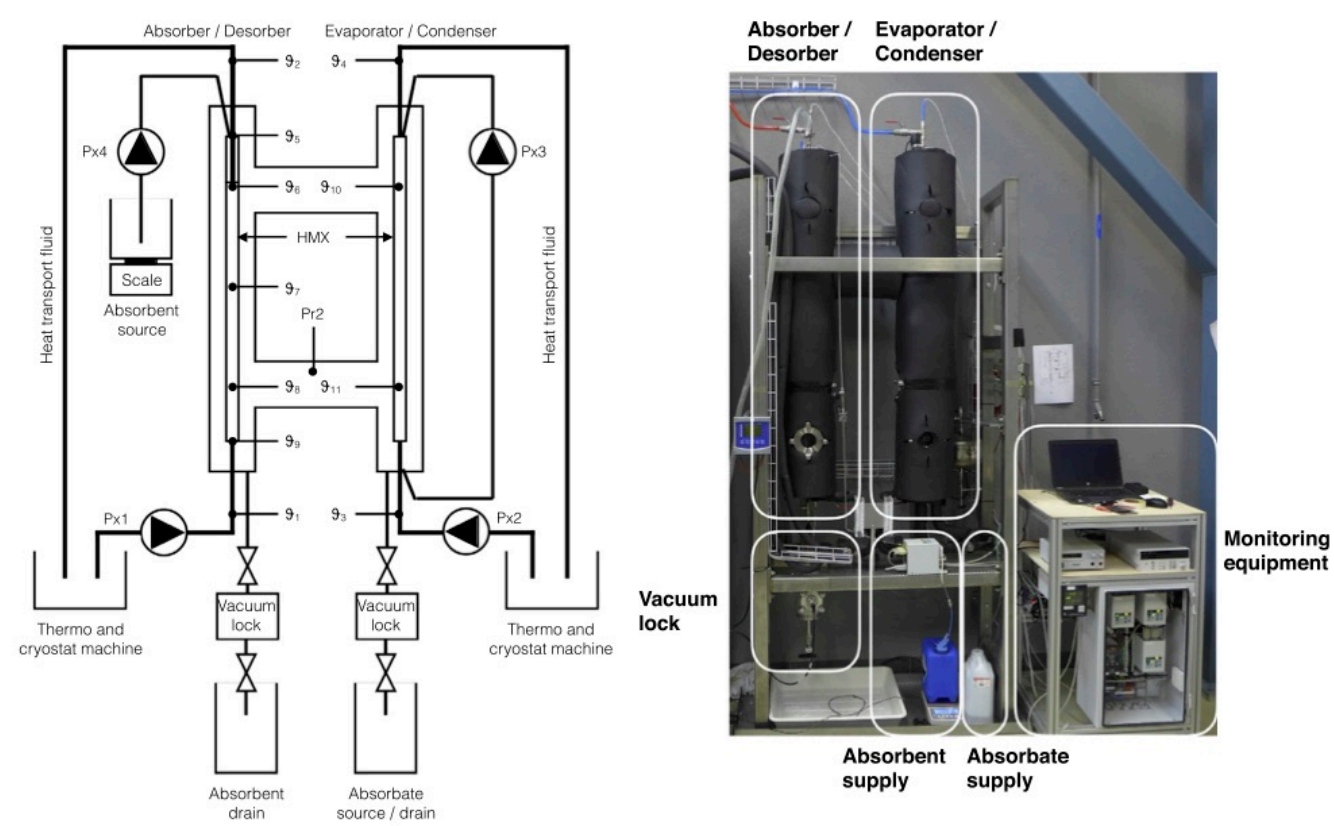

Figure 16: Left: Schematics of the closed transported system. Right: Picture of the lab scale setup [45].

At Tsinghua University, China, a closed transported system based on the working pair $\mathrm{LiBr}$ and water is reported [78]. Figure 17 shows the setup as well as operating temperatures. In desorption a temperature of $73{ }^{\circ} \mathrm{C}$ with a condensing temperature of $18{ }^{\circ} \mathrm{C}$ was applied, coherent to a GTL of $55 \mathrm{~K}$. In sorption, evaporator temperature was set to $12{ }^{\circ} \mathrm{C}$, reaching an average absorber temperature of $36^{\circ} \mathrm{C}$ resulting in a GTLs of $24 \mathrm{~K}$. In the setup a tube bundle falling film heat and mass exchanger is employed, and from the schematic illustration and the operation results it can be seen that the sorbent solution is circulated in order to reach good wetting. For this reason, steady state operation is not possible and energy density is reduced due to temperature breakthrough limitation. 

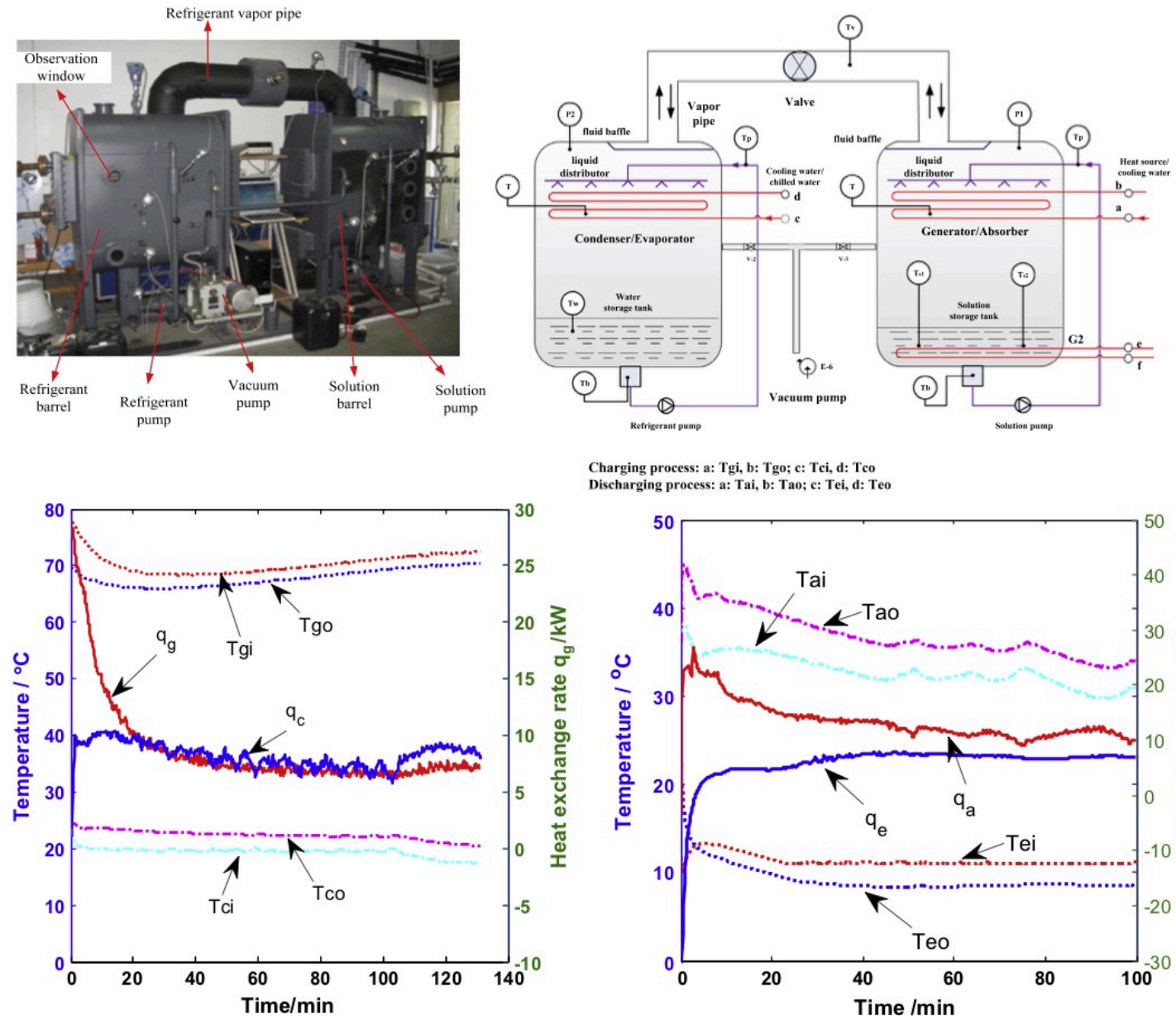

Charging process: a: Tgi, b: Tgo; c: Tci, d: Tco

Discharging process: a: Tai, b: Tao; c: Tei, d: Teo

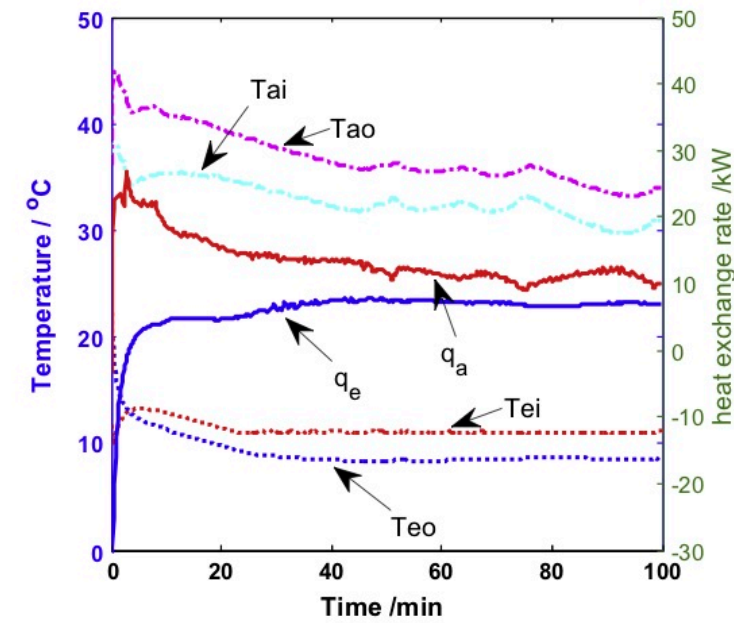

Figure 17: Top left: Picture of the test setup. Top right: Schematics of the system. Bottom left: Desorption operation result. Bottom right: sorption operation result [78].

At the University of Savoie, France work is performed on the $\mathrm{LiBr}$ and water working pair [79]. Desorption of the system was performed at $95^{\circ} \mathrm{C}$ and condensation at $20^{\circ} \mathrm{C}$ thus a $\mathrm{GTL}$ of $75 \mathrm{~K}$ was applied. It is reported that in sorption no temperature gain was reached. Figure 18 shows the setup as well as the testing result. 

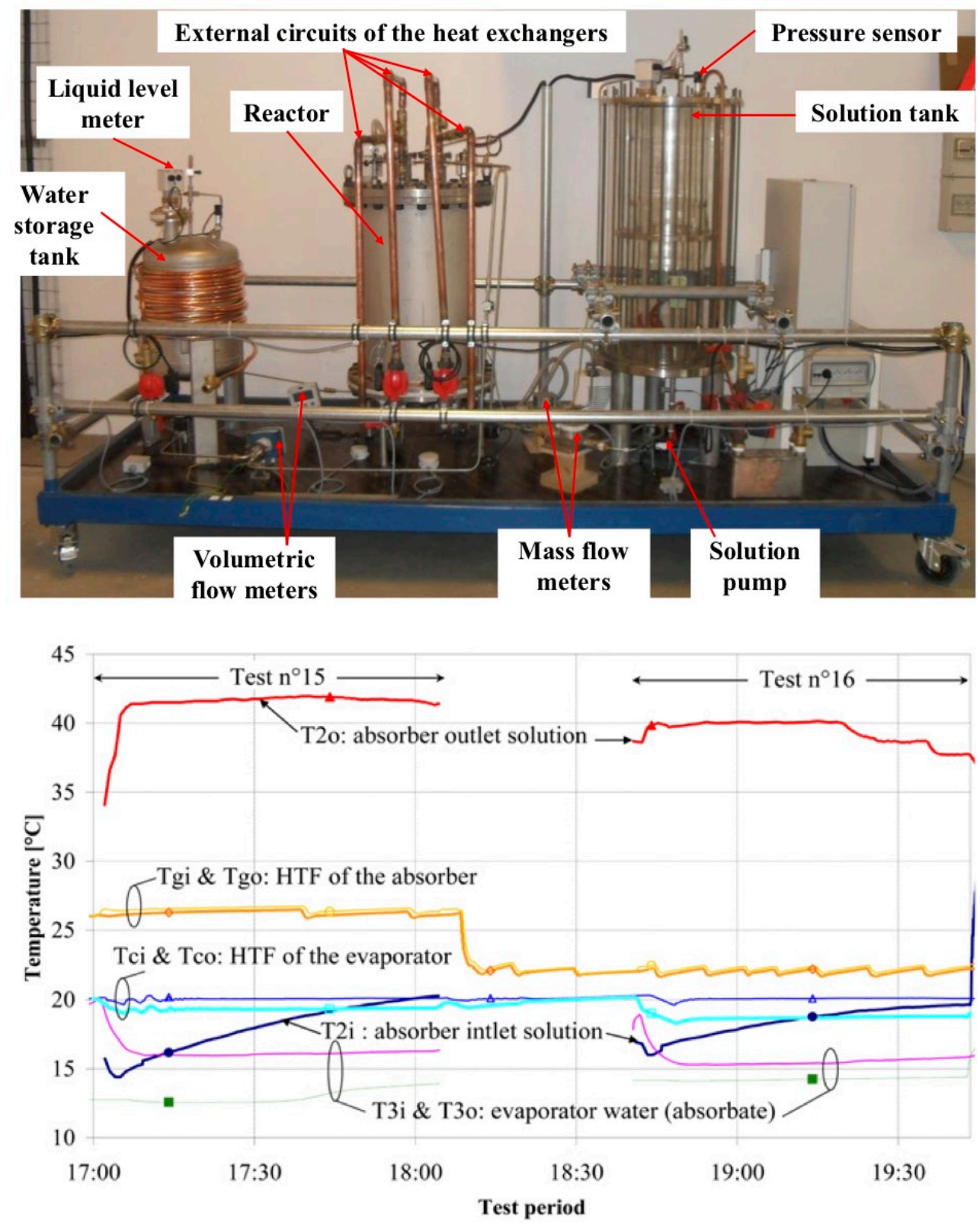

Figure 18: Top: Picture of the LiBr and water system. Bottom: Results of two sorption tests [79] 

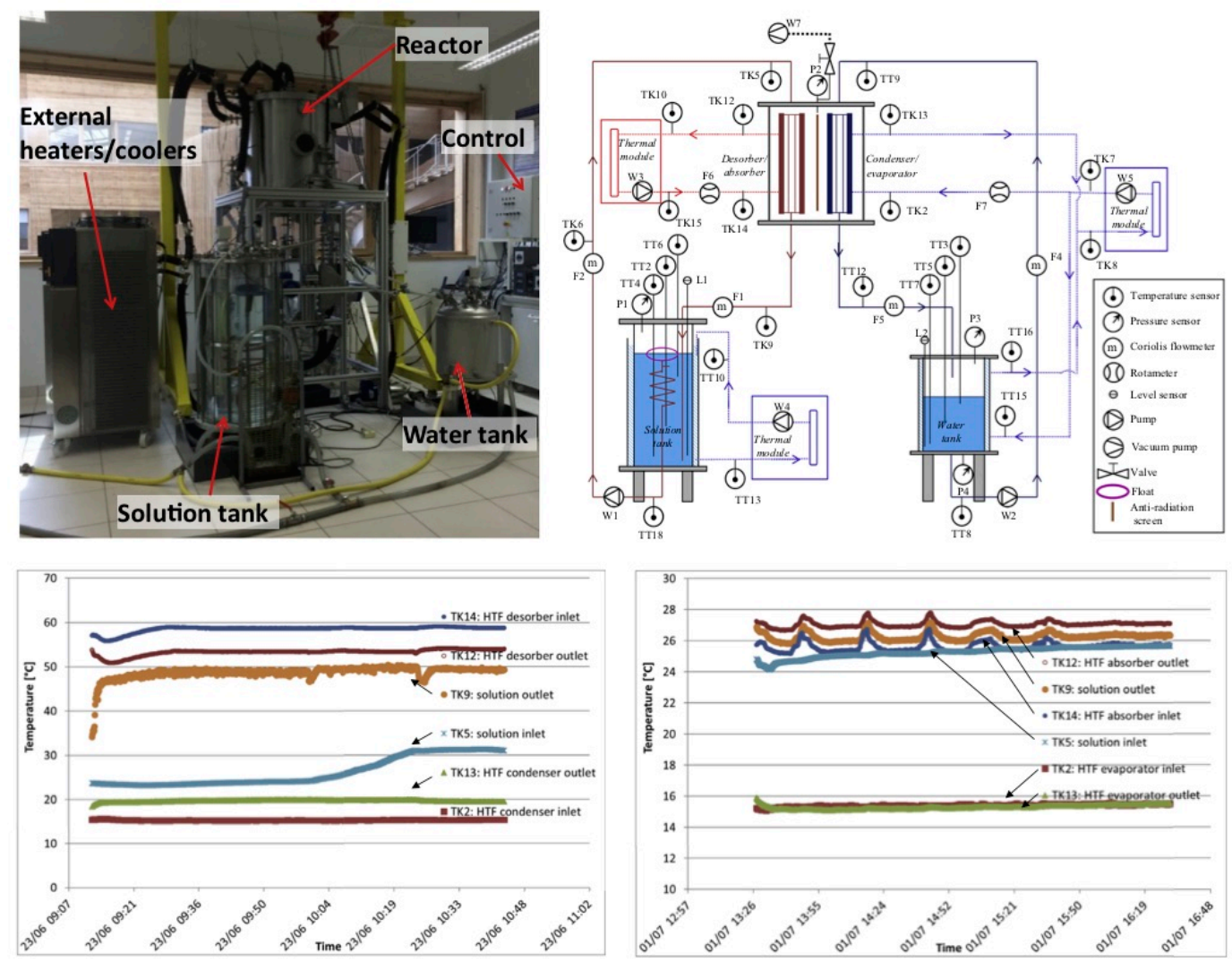

Figure 19: Top left: Picture of the $\mathrm{KCOOH}$ and $\mathrm{H} 2 \mathrm{O}$ test setup from the University of Savoie, France. Top right: Schematics of the setup. Bottom left: Results of the desorption test. Bottom right: Results of a sorption test [80].

Further research at the University of Savoie, is conducted based on $\mathrm{KCOOH}$ and $\mathrm{H}_{2} \mathrm{O}$ working pair [80]. The desorption process is performed at $59^{\circ} \mathrm{C}$ at a condensing temperature of $16{ }^{\circ} \mathrm{C}$ resulting in a GTL $L_{D}$ of $43 \mathrm{~K}$ as can be seen in figure 19. In sorption, an output temperature of $27^{\circ} \mathrm{C}$ is reached at an evaporator temperature of $15^{\circ} \mathrm{C}$ thus reaching a GTLs of $12 \mathrm{~K}$.

Other institutes working on closed transported systems are University of Minnesota, USA, based on $\mathrm{CaCl}_{2}$ and water working pair [81, 82], as well as University of Applied Science Rapperswil, Switzerland, working with $\mathrm{NaOH}$ and $\mathrm{H}_{2} \mathrm{O}$ focusing on the improvement of a tube bundle falling film type setup [83, 84].

\section{Discussion}

Examples from literature for the basic sorption thermal energy storage system designs are presented. It can be seen that there is no uniform approach for testing and evaluation followed in these examples. As a matter of fact, many tests are performed at ideal material temperatures rather than realistic application temperatures. From the pictures provided it is recognised that the systems are all at varying grades of development in term of technology readiness and scale. For these reasons it is impossible to compare the systems on basis of volumetric energy storage density and volumetric charge and discharge power density or even specific discharge output temperature. In order to enable a comparison of systems and especially basic processes as discussed, this study looks into the required $G T L_{D}$ for desorption, the resulting GTLs in sorption and its ratio GTLs / GTL $L_{D}$, defining the temperature effectiveness TE. This method describes how well the system takes advantage of the full potential of the employed storage material and enables a basic comparison between the systems as well as the basic process designs. Table 2 shows an overview of the reviewed systems. Since some reports provided insufficient indication of water vapour pressure in desorption, these were assumed and indicated in brackets in the table. 
Table 2: Overview of the evaluated systems with desorption $G T L_{D}$, sorption $G T L_{S}$ and temperature effectiveness (TE) as the ratio of GTLs to GTLD. Values based on assumptions are in brackets.

\begin{tabular}{|c|c|c|c|c|}
\hline System & Author & $\mathrm{GTL}_{\mathrm{D}}[\mathrm{K}]$ & $\mathrm{GTL}_{\mathrm{s}}[\mathrm{K}]$ & $\mathrm{TE}[\mathrm{K} / \mathrm{K}]$ \\
\hline \multirow[t]{7}{*}{ Open Fixed } & Johannes et al. [58] & $(165)$ & 43 & 0.26 \\
\hline & Tatsidjodoung et al. [44] & (165) & 44 & 0.27 \\
\hline & Michel et al. [61] & 62 & 19 & 0.31 \\
\hline & Weber et al. [42] & 172 & 42 & 0.24 \\
\hline & Zhang et al. [62] & (95) & 27 & 0.28 \\
\hline & Aydin et al. [63] & 120 & 21 & 0.18 \\
\hline & Gaeini et al. [60] & $(175)$ & 20 & 0.11 \\
\hline Open Transported & Nonnen et al. [64] & 173 & 50 & 0.29 \\
\hline \multirow[t]{7}{*}{ Closed Fixed } & Finck et al. [69] & 83 & 30 & 0.36 \\
\hline & Köll et al. [48] & 163 & 25 & 0.15 \\
\hline & Palomba et al. [70] & 60 & 25 & 0.42 \\
\hline & Zhao et al. [72] & 67 & 22 & 0.33 \\
\hline & Jiang et al. [73] & 136 & 47.4 & 0.35 \\
\hline & Brancato et al. [71] & 60 & 24.5 & 0.41 \\
\hline & Yan et al. [77] & 154 & 35 & 0.23 \\
\hline \multirow[t]{3}{*}{ Closed Transported } & Fumey et al. [45] & 55 & 23 & 0.42 \\
\hline & Zhang et al. [78] & 55 & 22 & 0.40 \\
\hline & Le Pierrès et al. [80] & 43 & 12 & 0.28 \\
\hline
\end{tabular}

From table 2 it can be seen that there are substantial performance differences of the systems in terms of TE. In general, it is important to consider that any $G T L_{D}$ beyond $80 \mathrm{~K}$ is not realistic with conventional solar thermal systems or domestic heat pumps. Thus, the respective test results are not directly relevant for the application in buildings.

A performance tendency based on the choice of basic system can be observed. Looking at the open fixed systems, those requiring a GTL $L_{D}$ above $100 \mathrm{~K}$, show a low TE from 0.11 to 0.27 . These are systems based on zeolite, which is the most studied solid material for long-term heat storage. In this comparison, these systems are generally larger scale, containing more storage material and are more developed towards the application. This, and the fact that zeolite due to its inherent high porosity is a very poor thermal conductor may lead to these low ratios. The systems with GTLD below $100 \mathrm{~K}$ also have higher TE between 0.28 to 0.31 . These work with salt impregnated materials and are generally at a smaller scale. Comparing the open fixed system results to the open transported system result, all but one TE is lower. This points to the tendency of better performance in transported systems due to the continuous process with introduction of fresh sorbent in order to reach high GTLs. There is a variation of performance in the closed fixed system, again with zeolite based systems requiring substantially greater $G T L_{D}$ and having lower $T E$. In part, this has to do with the size of the system as with the open fixed design. Comparing only the zeolite based systems, thus providing a more common ground, it can be concluded that closed fixed systems perform better than open fixed ones and the open transported system reaches a higher TE than the closed fixed system. The comparison cannot be continued to the closed transported approach, since there is no known closed transported system based on zeolite. The closed transported systems are all based on liquid sorbents since these can easily be pumped for transportation. TE is generally higher in this approach in comparison to all other process options.

\section{Conclusion}

This study categorises sorption thermal energy storage systems into four basic process designs; open fixed, open transported, closed fixed and closed transported. A literature review on process and system designs and performance is composed, following the respective basic process categories. Temperature effectiveness defined as the ratio of GTLs in sorption to $G T L_{D}$ in 
desorption mode is used as a temperature management performance metric. It is shown that performance of the storage material and hence the exploitation of its potential is dependent on the process design, whereby the transported approach is favoured to fixed bed and the closed system approach performs better than the open one. Over all, the closed and transported system approach is seen to have the highest performance potential in terms of temperature effectiveness. A future challenge to be addressed may thus be mass transport of solid sorbents in closed transported systems.

\section{Acknowledgement}

This research work is financially supported by the Swiss Innovation Agency Innosuisse grant Nr. 1155002545 and is part of the Swiss Competence Center for Energy Research SCCER HaE. Supplementary funding is received from the Swiss Federal Office of Energy SFOE grant $\mathrm{Nr}$. SI/501605-01 in the frame of the IEA SHC Task 58/ECES Annex 33 participation.

\section{List of References}

[1] Rommel M, Hauer A, van Helden W. IEA SHC Task 42 / ECES Annex 29 Compact Thermal Energy Storage. Enrgy Proced 2016;91;226-30.

[2] Bales C. Solar cooling and storage with the thermo-chemical accumulator. In: Proceedings of Eurosun; 2006.

[3] International Energy Agency, Solar Heating and Cooling Task 32 - Advanced Storage Concepts for Solar and Low Energy Buildings, http://task32.iea-shc.org; 2019 [accessed 10 January 2019]

[4] International Energy Agency, Solar Heating and Cooling Task 42 - Compact Thermal Energy Storage http://task42.iea-shc.org; 2019 [accessed 10 January 2019]

[5] International Energy Agency, Solar Heating and Cooling Task 58, Material and Component Development for Thermal Energy Storage http://task58.iea-shc.org; 2019 [accessed 10 January 2019]

[6] van Helden W, Yamaha M, Rathgeber Ch, Hauer A, Huaylla F, Le Pierrès N, Stutz B, Mette B, Dolado P, Lazaro A, Mazo J, Dannemand M, Furbo S, Campos-Celador A, Diarce G, Cuypers R, König-Haagen A, Höhlein S, Brüggemann D, Fumey B, Weber R, Köll R, Wagner W, DaguenetFrick X, Gantenbein P, Kuznik F. IEA SHC Task 42 / ECES Annex 29 - Working Group B: Applications of Compact Thermal Energy Storage. Enrgy Proced 2016;91:231-45.

[7] International Energy Agency, Energy Technology Perspectives Report 2016 ISBN: 978-9264-25233-2

[8] Rathgeber Ch, Hiebler S, Lävemann E, Dolado P, Lazaro A, Gasia J, de Gracia A, Miró L, Cabeza LF, König-Haagen A, Brüggemann D, Campos-Celador A, Franquet E, Fumey B, Dannemand M, Badenhop T, Diriken J, Nielsen JE, Hauer A. IEA SHC Task 42 / ECES Annex 29 - A Simple Tool for the Economic Evaluation of Thermal Energy Storages. Enrgy Proced 2016;91:197-206.

[9] Kabus, F, Wolfgramm, M. Aquifer thermal energy storage in Neubrandenburg -Monitoring throughout three years of regular operation. In: Proceedings of 11th International Conference on Thermal Energy Storage; 2009.

[10] Dannemand M, Johansen JB, Kong W, Furbo S. Experimental investigations on cylindrical latent heat storage units with sodium acetate trihydrate composites utilizing supercooling. Appl Energ 2016;177:591-601. 
[11] Englmair G, Moser Ch, Furbo S, Dannemand M, Fan J. Design and functionality of a segmented heat-storage prototype utilizing stable supercooling of sodium acetate trihydrate in a solar heating system. Appl Energ 2018;221:522-34.

[12] Garg HP, Mullick SC, Bhargava AK. Solar thermal energy storage. Dordrecht: Reidel Publishing Company; 1985.

[13] Zondag HA. Sorption Heat Storage. In: Sørensen B, editor. Solar Energy Storage. Netherlands: Academic Press; 2015, p. 135-54.

[14] Hauer A. Sorption theory for thermal energy storage. In: Paksoy HÖ, editor. Thermal energy storage for sustainable energy consumption. Netherlands: Springer; 2007. p. 393-408.

[15] Kawasaki H, Watanabe T, Kanzawa A. Proposal of a chemical heat pump with paraldehyde depolymerization for cooling system. Appl. Therm. Eng. 1999;19(2):133-43

[16] Boman BD, Hoysall DC, Staedter M A, Goyal A, Ponkala M J, Garimella S. A method for comparison of absorption heat pump working pairs. Int. J. Refrig. 2017;77:149-75.

[17] Aristov Y I. Challenging offers of material science for adsorption heat transformation: A review. Appl. Therm. Eng. 2013;50(2):1610-8.

[18] N'Tsoukpoe KE, Liu H, Le Pierrès N, Luo L. A review on long-term sorption solar energy storage. Renew Sust Energ Rev 2009;13(9):2385-23.

[19] Cabeza LF, Solé A, Barreneche C. Review on sorption materials and technologies for heat pumps and thermal energy storage. Renew Energ 2017;110;3-39.

[20] Perry RH. Perry's Chemical Engineers' Handbook. 8th ed. McGraw-hill 2007.

[21] Vasiliev LL, Kulakov AG. Heat pipe applications in sorption refrigerators. In: Sadık Kakac, HFS, Avelino MR, editors. Low temperature and cryogenic refrigeration: proceedings of the NATO advanced study institute. Netherlands: Springer; 2003 p. 401.

[22] Inglezakis VJ, Poulopoulos S. Adsorption, ion exchange and catalysis: design of operations and environmental applications. Elsevier; 2006.

[23] Bales C. Thermal Properties of Materials for Thermo-chemical Storage of Solar Heat. A Report of IEA Solar Heating and Cooling programme - Task 32; 2005.

[24] Kato Y. Chemical energy conversion technologies for efficient energy use, Thermal energy storage for sustainable energy consumption. Netherlands: Springer; 2007. p. 377-91.

[25] ASHRAE handbook: fundamentals, I-P edition, Atlanta: American Society of Heating, Refrigerating and Air-Conditioning Engineers; 2005 p. 1.13-1.5.

[26] Wongsuwan W, Kumar S, Neveu P, Meunier F. A review of chemical heat pump technology and applications. Appl Therm Eng 2001;21(15): 1489-519.

[27] Kuznik F, Johannes K, Obrecht Ch, David D. A review on recent developments in physisorption thermal energy storage for building applications. Renew Sust Energ Rev 2018;94:576-86.

[28] Palomba V, Frazzica A. Recent advancements in sorption technology for solar thermal energy storage applications. Sol Energ 2018; in press.

[29] Solé A, Martorell I, Cabeza LF. State of the art on gas-solid thermochemical energy storage systems and reactors for building applications. Renew Sust Energ Rev 2015;47:386-98. 
[30] Yu N, Wang RZ, Wang LW. Sorption thermal storage for solar energy. Prog Energ Combust, 2013;39:489-514.

[31] Abedin AH, Rosen M A. A critical review of thermochemical energy storage systems. The Open Renewable Energy Journal 2011;4:42-6.

[32] Scapino L, Zondag HA, Van Bael J, Diriken J, Rindt CCM. Sorption heat storage for longterm low-temperature applications: A review on the advancements at material and prototype scale, Appl Energ, 2017;190:920-948.

[33] Fumey B, Weber R, Gantenbein P, Daguenet-Frick X, Hughes I, Dorer V. Limitations Imposed on Energy Density of Sorption Materials in Seasonal Thermal Storage Systems, Enrgy Proced, 2015;70:203-208.

[34] Finck Ch, Li R, Kramer R, Zeiler W. Quantifying demand flexibility of power-to-heat and thermal energy storage in the control of building heating systems, Appl Energ, 2018;209:409-425.

[35] Scapino L, Zondag HA, Van Bael J, Diriken J, Rindt CCM. Energy density and storage capacity cost comparison of conceptual solid and liquid sorption seasonal heat storage systems for low-temperature space heating, Renew Sust Energ Rev, 2017;76:1314-1331.

[36] Hadorn JC. IEA solar heating and cooling programme-Task 32: Advanced storage concepts for solar and low energy buildings. In: Proceedings of ECO- STOCK; 2006.

[37] N'Tsoukpoe KE, Le Pierrès N, Luo L. Experimentation of a LiBr-H2O absorption process for long-term solar thermal storage: prototype design and first results. Energy 2013;53:179-98.

[38] Kerskes H, Mette B, Bertsch F, Asenbeck S, Drück H. Development of a Thermo-Chemical Energy Storage for Solar Thermal Applications. In Proceedings of ISES, Solar World Congress 2013.

[39] Zondag H, Kikkert B, Smeding S, de Boer R, Bakker M. Prototype thermochemical heat storage with open reactor system. Appl Energ 2013;109:360-5.

[40] Weber R, Dorer V. Long-term heat storage with $\mathrm{NaOH}$. Vacuum 2008;82(7):708-16.

[41] Kerskes H, Mette B, Bertsch F, Asenbeck S, Drück H. Development of a Thermo-Chemical Energy Storage for Solar Thermal Applications. In: Proceedings of ISES Solar World Congress; 2011.

[42] Weber R, Asenbeck S, Kerskes H, Drück H. SolSpaces - Testing and performance analysis of a segmented sorption store for solar thermal space heating. Enrgy Proced 2016;91:250-8.

[43] van Alebeek R, Scapino L, Beving MAJM, Gaeini M, Rindt CCM, Zondag HA. Investigation of a household-scale open sorption energy storage system based on the zeolite 13X/water reacting pair. Appl Therm Eng 2018,139:325-33.

[44] Tatsidjodoung P, Le Pierrès N, Heintz J, Lagre D, Luo L, Durier F. Experimental and numerical investigations of a zeolite $13 \mathrm{X} /$ water reactor for solar heat storage in buildings. Energ Convers Manage 2016;108:488-500.

[45] Fumey B, Weber R, Baldini L. Liquid sorption heat storage - A proof of concept based on lab measurements with a novel spiral fined heat and mass exchanger design, Appl Energ 2017;200:215-25. 
[46] de Boer R, Haije W, Veldhuis J, Smeding S. Solid sorption cooling with integrated storage: the SWEAT prototype. In: Proceedings of 3rd international heat powered cycles conference; 2004.

[47] Hauer A. Sorption storages for solar thermal energy_-possibilities and limits. In: Proceedings of the Eurosun; 2008.

[48] Köll R, van Helden W, Engel G, Wagner W, Dang B, Jänchen J, Kerskes H, Badenhop T, Herzog T. Experimental Investigation of a realistic scale seasonal solar sorption storage system for buildings. Sol Energ 2017;155:388-97.

[49] Zondag $\mathrm{H}$, Kalbasenka A, van Essen M. First studies in reactor concepts for thermochemical storage. In: Proceedings of the Eurosun; 2008.

[50] Baghapour B, Rouhani M, Sharafian A, Kalhori SB, Bahrami M. A pressure drop study for packed bed adsorption thermal energy storage, Appl Therm Eng 2018;138:731-9.

[51] Mette B, Kerskes H, Drück H. Concepts of long-term thermochemical energy storage for solar thermal applications - Selected examples, Enrgy Proced, 2012;30:321-30.

[52] Jaehnig D, Hausner R, Wagner W, Isaksson C. Thermo-chemical storage for solar space heating in single-family house. In: ECOSTOCK conference; 2006.

[53] de Jong AJ, van Vliet L, Hoegaerts Ch, Roelands M, Cuypers R. Thermochemical Heat Storage - from Reaction Storage Density to System Storage Density, Enrgy Proced 2016;91:12837.

[54] Krönauer A, Lävemann E, Brückner S, Hauer A. Mobile Sorption Heat Storage in Industrial Waste Heat Recovery. Enrgy Proced 2015;73:272-80.

[55] Mette B, Kerskes H, Drück H. New high efficient regeneration process for thermo-chemical energy stores. In: Proceedings of Innostock: 2012.

[56] Boman DB, Hoysall DC, Pahinkar DG, Ponkala MJ, Garimella S. Screening of working pairs for adsorption heat pumps based on thermodynamic and transport characteristics. Appl Therm Eng 2017;123:422-34.

[57] Fumey B, Weber R, Gantenbein P, Daguenet-Frick X, Williamson T, Dorer, V. Parameters effecting economy and heat density of sorption heat storage systems. In: Eurtherm Seminar 99: 2014.

[58] Johannes K, Kuznik F, Hubert JL, Durier F, Obrecht C. Design and characterisation of a high powered energy dense zeolite thermal energy storage system for buildings. Appl Energ 2015;159:80-6.

[59] Aydin D, Casey SP, Chen X, Riffat S. Numerical and experimental analysis of a novel heat pump driven sorption storage heater. Appl Energ 2018;211:954-74.

[60] Gaeini M, Javed MR, Ouwerkerk H, Zondag HA, Rindt CCM. Realization of a 4kW thermochemical segmented reactor in household scale for seasonal heat storage. Enrgy Proced 2017;135:105-14.

[61] Michel B, Mazet N, Neveu P. Experimental investigation of an innovative thermochemical process operating with a hydrate salt and moist air for thermal storage of solar energy: global performance. Appl Energ 2014;129:177-86.

[62] Zhang YN, Wang RZ, Li TX. Experimental investigation on an open sorption thermal storage system for space heating. Energy 2017;141:2421-33. 
[63] Aydin D, Casey SP, Chen X, Riffat S. Novel "open-sorption pipe" reactor for solar thermal energy storage. Energ Convers Manage 2016;121:321-34.

[64] Nonnen T, Beckert S, Gleichmann K, Brandt A, Unger B, Kerskes H, Mette B, Bonk S, Badenhop T, Salg F, Gläser R. A Thermochemical long-term heat storage system based on a salt/zeolite composite. Chem Eng Technol 2016;39:2427-34.

[65] Mette B, Kerskes $\mathrm{H}$, Drück $\mathrm{H}$. Experimental and numerical investigations of different reactor concepts for thermochemical energy storage. Enrgy Proced 2014;57:2380-89.

[66] Mette B, Kerskes H, Drück H, Müller-Steinhagen H. New highly efficient re- generation process for thermochemical energy storage. Appl Energ 2013;109:352-59.

[67] Skrylnyk O, Courbon E, Heymans N, Frère M, Bougard J, Descy G. Performance characterization of salt-in-silica composite materials for seasonal energy storage design. J Energ Stor 2018;19;320-36.

[68] Wyttenbach J, Bougard J, Descy G, Skrylnyk O, Courbon E, Frère M, Bruyat F. Performances and modelling of a circular moving bed thermochemical reactor for seasonal storage. Appl Energ 2018;230:803-15.

[69] Finck C, Henquet E, van Soest C, Oversloot H, de Jong AJ, Cuypers R, van't Spijker H. Experimental Results of a $3 \mathrm{kWh}$ Thermochemical Heat Storage Module for Space Heating Application. Enrgy Proced 2014;48:320-6.

[70] Palomba V, Vasta S, Freni A, Experimental testing of AQSOA FAM Z02/water adsorption system for heat and cold storage. Appl Therm Eng 2017;124:967-74.

[71] Brancato V, Gordeeva LG, Sapienza A, Palomba V, Vasta S, Grekova AD, Frazzica A, Aristov YI. Experimental characterization of the $\mathrm{LiCl} /$ vermiculite composite for sorption heat storage applications, Int. J. Refrig., 2018 in press.

[72] Zhao YJ, Wang RZ, Li TX, Nomura Y. Investigation of a $10 \mathrm{kWh}$ sorption heat storage device for effective utilization of low-grade thermal energy. Energy 2016;113:739-47.

[73] Jiang L, Wang RZ, Wang LW, Roskilly AP. Investigation on an innovative resorption system for seasonal thermal energy storage, Energ Convers Manage, 2017;149:129-139.

[74] Mauran S, Lahmidi H, Goetz V. Solar heating and cooling by a thermochemical process: First experiments of a prototype storing $60 \mathrm{kWh}$ by a solid/gas reaction. Sol Energ 2008;82(7):62336.

[75] Li TX, Xu JX, Yan T, Wang RZ. Development of sorption thermal battery for low-grade waste heat recovery and combined cold and heat energy storage. Energy 2016;107:347-59.

[76] Li TX, Wu S, Yan T, Wang RZ, Zhu J. Experimental investigation on a dual- mode thermochemical sorption energy storage system. Energy 2017;140:383-94.

[77] Yan T, Wang RZ, Li TX, Experimental investigation on thermochemical heat storage using manganese chloride/ammonia. Energy 2018;143:562-74.

[78] Zhang X, Li M, Shi W, Wang B, Li X. Experimental investigation on charging and discharging performance of absorption thermal energy storage system. Energ Convers Manage 2014;85:425-34.

[79] N'Tsoukpoe KE, Le Pierrès N, Luo L, Experimentation of a LiBr-H2O absorption process for long term solar thermal storage. Enrgy Proced 2012;30:331-41. 
[80] Le Pierrès N, Huaylla F, Stutz B, Perraud J. Long-term solar heat storage process by absorption with the $\mathrm{KCOOH} / \mathrm{H} 2 \mathrm{O}$ couple: experimental investigation. Energy 2017;141:1313-23.

[81] Quinnell JA, Davidson JH, Burch J. Liquid calcium chloride solar storage: concept and analysis. In: Proceedings of ASME; 2010.

[82] Quinnell, JA, Davidson JH. Mass transfer during sensible charging of a hybrid absorption/sensible storage tank. Enrgy Proced 2012;30:353-61.

[83] Daguenet-Frick X, Gantenbein P, Müller J, Fumey B, Weber R. Seasonal thermochemical energy storage: Comparison of the experimental results with the modelling of the falling film tube bundle heat and mass exchanger unit, Renew Energ 2017;110:162-73.

[84] Daguenet-Frick X, Dudita M, Omlin, Gantenbein P. Seasonal Thermal Energy Storage with Aqueous Sodium Hydroxide - Development and Measurements on the Heat and Mass Exchangers, Enrgy Proced 2018;155:286-294. 